\title{
MITO Y MEMORIA, MUERTE Y MORAL: CAREO DE TRES SONETISTAS DE LA CONTRARREFORMA (ARGUIJO, MARTÍN DE LA PLAZA Y TEJADA) ${ }^{1}$
}

\author{
Gaspar Garrote Bernal \\ Universidad de Málaga
}

En el principio fueron Juan de Arguijo, Agustín de Tejada Páez y Luis Martín De la Plaza

1. Ajena al arbitrario azar, la reflexión se juzgó signo para detectar tanto al capaz de "estimar los tesoros" de la poesía, "ciencia" que "se ha de servir" de "todas las otras ciencias", como a los poetas que no "son meros romancistas", al decir de un don Quijote (II, 16) concebido básicamente en Andalucía, donde el manierismo - según Orozco - "se manifiesta con pleno carácter de estilo". De modo que la práctica de tal estilo (el del humanismo contrarreformista [Valderrama Andrade]) implicó, en ciudades como Sevilla, Granada, Antequera o Córdoba, reflexión académica (quiero decir, en academias), y el arrimo de los poetas científicos o no romancistas a comentadores

1 Recibido: 12/I/2010 Aceptado: 2/III/2010 
que los guiaran con su saber, como muestran las parejas de Herrera y Francisco de Medina, Lope de Vega y Arguijo, Arguijo y otra vez Medina, de nuevo Lope y Espinel, o Góngora y Pedro de Valencia.

2. Es posible que las antologías que conservaron memoria poética contrarreformista de Antequera y Granada respondan a una ordenación en algo sujeta al azar; pero también que, en cada florilegio, la selección del primer poema haya respondido a una meditada intención, acorde con las exigencias, particularmente vivas en Andalucía, de un arte repensado. Así, en la apertura de su colectánea, Espinosa eligió siete composiciones de otros tantos autores, casi todos representativos de lo que iba a ser el curso de las Flores de poetas ilustres: Arguijo, Góngora, Lupercio de Argensola, Martín de la Plaza, el propio antólogo, Quevedo e incluso el conde de Salinas. Molina Huete argumentó convincentemente contra el azar como factor para entender la tarea de Espinosa, y atendió a Ticknor, para quien, yendo el primero, Arguijo lograba para las Flores "el favor y aplauso del público, dada su fama como poeta y como protector de vates", fama de mecenas que, como indicó Prieto, fue reconocida por los sevillanos.

3. Recolectemos otros hechos: la «Canción a Nuestra Señora», del antequerano Tejada, inaugura la granadina Poética silva (h. 1602); en el pórtico de las Flores de poetas ilustres (1605), compiladas por otro singilitano, Pedro Espinosa, figura el soneto "La tirana codicia del hermano...", del sevillano Arguijo; la antología antequerana de las Flores (1611) de Calderón se inicia con la atribución a este poeta de "Una alta compasión envuelta en ira...", canción que no pertenece al corpus arguijiano, lo cual no quita que esta otra colectánea principie con el nombre de Arguijo; y en la apertura del volumen III del conocido como Cancionero antequerano, que compiló Toledo y Godoy (1628), se sitúa «A las once mil vírgenes», del singilitano Luis Martín de la Plaza, un poema definido por Lara Garrido como de "taracea" y "afortunado ejercicio de imitación compuesta". (En efecto, estimo que esta canción no sólo calca otra de Espinosa, sino que incluye sintagmas típicos de Martín de la Plaza, como ese viento en popa [v. 19] que no figura en el modelo, pero sí en MP 65, v. 14.) Mi propósito ahora es diseminar y recolectar, comparándolos, algunos sonetos de esos tres autores que, inaugurando antologías, otras copando, algo debieron de simbolizar y sintetizar, para sus contemporáneos, el quehacer lírico de lo que mucho después se llamaría manierismo: Juan de Arguijo (1567-1622 [en adelante, A]), a quien prestó especial atención el círculo antequerano; Agustín de Tejada Páez (1567-1635 [T]), principal vínculo entre granadinos y singilitanos, como recordó Roses; y Luis Martín de la Plaza (1577-1625 [MP]), el favorito de Antequera. Frente a Herrera, ausente de las tres antologías de 1605, 1611 y 1627-1628, según subrayó Morata Pérez, Arguijo figura en ellas con 6, 23 y 11 sonetos, respectivamente; Tejada, con 5, 5 y 23 poemas, y De la Plaza nada menos que con 25, 46 y 103 composiciones. Mi cotejo o - a lo gracianesco - careo, buscará contigüidades temáticas, estilísticas y de efecto; en lo 
que el efecto, ese fantástico productor de indicios, sea aquí sinónimo de intencionalidad. Signo de su tiempo, tal finalidad apenas podía ser otra que contrarreformista.

\section{EN EL PRINCIPIO FUE EL MITO}

4. La ironía de situación es recurso por el que los espectadores de la tragedia griega saben más que los propios personajes sobre el discurrir de la acción. Análogamente, para los poetas del Siglo de Oro presentó la mitología la particularidad de que, no habiendo historia cuyo desenlace no conocieran sus receptores, el esfuerzo hubo de hacerse en la selección de una secuencia del relato mítico, en la conexión de tal segmento con un pensamiento - si no de otra índole, preferentemente moral- y en la disposición técnica, mimada artesanalmente, del nuevo producto verbal que volcaba la vieja materia. Obviar esto desenfoca la cuestión y conlleva anacronismo interpretativo: tiene razón Vranich al sostener que recontar las gestas de Hércules "en el menor espacio posible" adquirió el rasgo de "prueba de habilidad" poética áurea, pero carece de sentido histórico su apostilla final: "Se trata, pues, más de un ejercicio técnico que de una verdadera creación poética". ¿Y qué diferencia podía haber, desde la ultraconsciencia artística contrarreformista, entre uno y otra? Porque lo cierto es que "el poeta clásico no extrae la inspiración de su sentimiento, sino de su dominio técnico" (Carreira).

5. Arguijo y Martín de la Plaza se sumaron al competir - igual de academia sobre el asunto de Hércules. Contemplando los dos sonetos siguientes como un todo, MP 67 atiende las secciones inicial y final del argumento, mientras que A 52 se centra en los famosos trabajos (secuencia 2) y en la final derrota de amor (secuencia 3):

MP 67: secuencias 1 y 4 [predicción de la vida de Hércules; premio]

¡Oh grande niño y del mejor planeta hijo famoso!, oprime fuertemente, de una y otra, que ves, feroz serpiente, el cuerpo undoso y la garganta aprieta.

Desde pequeño, con valor, sujeta de tu madrastra el odio y celo ardiente, y enséñate a sufrir con firme frente las llamas que te aguardan en Oeta.

Que el premio que tendrás de tu fatiga será inmortal, pues que tu nombre impreso dejarás en columnas de diamante;

y entre los dioses tu constancia obliga, que después, hecho dios, te tenga en peso el cielo, a quien serás segundo Atlante.
A 52: secuencias 2 y 3

[autobiografía de Hércules; prisión de amor]

«El jabalí de Arcadia, el lëón nemeo y el toro a los cien pueblos pavoroso, cayeron a mis pies, $\mathrm{y}$ vitorioso de la Hidra me vio el lago Lerneo.

»El can de tres gargantas y Tifeo, fieras guardas del claustro tenebroso, no estorbaron mi intento generoso, ni le valió caer al fuerte Anteo.

»Ejemplos de mi ilustre vencimiento son Aqueloo, Busiris y Diomedes, y el rey a quien huir Hesperia mira.

»Mas, ¿por qué ufano más vitorias cuento, cativo en tu prisión? ¡Cuánto más puedes si me rendiste, oh bella Deyanira!» 
El "héroe máximo de la mitología clásica", hijo de Júpiter (el mejor planeta de MP 67), será perseguido por la esposa de éste, Hera (Juno), quien empezó por enviarle dos serpientes que el niño, aún en la cuna, estranguló. Hombre ya de enorme estatura, protagonizó hazañas que, siendo "la gran empresa de Hera para aniquilar a Hércules", deparan a éste "gloriosa fama". En Delfos, la Pitia pone su nombre al héroe y le anuncia que debe acometer diez (según "la tradición mítica genuina"; en otros testimonios antiguos son doce) trabajos, tras los cuales será inmortal; a punto de morir, el héroe manda que lo quemen en el "monte Eta" sobre una "enorme pira", cuyo "fuego devora la parte mortal de Hércules", mientras que "su parte inmortal", "trasladada al cielo", es "divinizada", después de lo cual Hera se reconcilia "con su hijastro". De acuerdo con lo anterior, que dicta Ruiz de Elvira, creo que la voz de MP 67 podría representar a la pitonisa délfica. Mediante la ironía de situación, el locutor de este soneto predice el completo futuro de Hércules: ha de estrangular a dos serpientes, enfrentarse al "odio y celo" de Juno y sufrir "las llamas que te aguardan en Oeta". Es una predicción conducida como serie de consejos, que verbalizan cuatro imperativos distribuidos en los cuartetos: oprime, aprieta, sujeta, enséñate. Por su parte, el autor, Martín de la Plaza, emplea artificios de complicación del discurso para dar forma nueva al viejo tema que todos, menos el Hércules niño, conocían. El alambicamiento es semántico en la perífrasis ("del mejor planeta / hijo famoso") y la alusión (tu madrastra; Oeta; segundo Atlante; las columnas de diamante que colocó el héroe durante su décimo trabajo, consistente en llevar vivas a Micenas las vacas de Gerión); pero también es formal en el encabalgamiento abrupto, que rige el primer cuarteto y parte del segundo, y en el hipérbaton: "de una y otra, que ves, feroz serpiente". Por lo demás, recurren el oxímoron (grande niño) y la variada adjetivación, que tiende a anteponerse: feroz serpiente, firme frente, grande niño, cuerpo undoso. Esta complicación - o alejamiento de la lengua estándar - puede verse como la consecuencia de que MP 67 no renunció al trato con un asunto carente de novedad: otro factor de una posible definición del probable manierismo o del acaso más seguro humanismo contrarreformista.

6. La ultra-adjetivación es frecuente también en Arguijo: en A 31, los "epítetos" (no todos antepuestos) vitorioso, esquiva, antigua, abundosa, fuerte y altiva son "ricos en poder evocador", y en el primer cuarteto de A 21 se acumulan ocho adjetivos, "uno para cada sustantivo", según analizó Vranich, quien adujo este pasaje de Juan de Robles, otro - como Arguijo - discípulo de Medina: “Aprovechan mucho los epítetos para resolver materias y historias largas, acabándolas brevemente para pasar a otras más propias del intento de que se habla" (El culto sevillano). Por su parte, Cristóbal reconoció la "perífrasis encubridora del nombre propio" como "un uso poético muy arraigado" en Arguijo. La misma falta de riesgo argumental de MP 67 había sido 
abordada por éste en el alarde técnico de A 52: el de verter los trabajos de Hércules en once versos y rematar cambiando de tema. El semidiós como "víctima de los celos de Deyanira" "es la idea central" de A 52, "a la que está condicionada su estructura: en los once primeros versos el mismo Hércules pasa revista a sus grandes victorias, solamente para concluir que fue vencido por una mujer" (Vranich); en efecto, con el relato del XI de Metamorfosis al fondo, Deyanira, creyendo haber perdido el amor de Hércules, provoca involuntariamente su muerte y luego se suicida (Ruiz de Elvira). A punto está Arguijo de lograr su reto, encajando ocho de las gestas mediante variados procedimientos: a) mencionando directamente la cuarta, llevar vivo al jabalí de la arcádica montaña de Erimanto; la primera, conseguir la piel del león de Nemea (v. 1), y la segunda (vv. 3-4), matar a la Hidra del lago Lerna; b) evocando con perífrasis el séptimo trabajo, capturar vivo al toro salvaje de Minos, que después causó estragos en Maratón (v. 2), y el duodécimo, atrapar en el Infierno a Cerbero, perro de tres cabezas (vv. 5-6); c) aludiendo a parergas o hazañas accesorias: durante su undécimo trabajo, consistente en traer las manzanas de oro de las Hespérides, Hércules mató al africano rey Anteo (v. 8) y a Busiris, monarca de Egipto (v. 10), y d) nombrando a personajes relacionados con las gestas, así Diomedes (v. 10), rey de Tracia, que poseía las yeguas antropófagas que el héroe llevó a Micenas en su octavo trabajo; y también Deyanira: Aqueloo (v. 10), pretendiente de ésta, es el río al que vence Hércules. Estimo que quizá el "cayeron a mis pies" (v. 3) que trae el primer posesivo del poema, valga asimismo por una afirmación de orgullo de Arguijo, que se supo capaz de troquelar en sus concisos versos (pies) el amplio discurrir de las hazañas del héroe. Que el artífice redujo a la breve urna de un soneto. Ante la extrañeza de Vranich, Arguijo sitúa a Tifeo junto con Cerbero; cruce de canes que, procediendo de Eneida, VIII, 296299 (Garrote Bernal-Cristóbal), menciona al "perro bicéfalo Orto, hijo de Equidna y Tifoeo" (Ruiz de Elvira), que en el décimo trabajo de Hércules guardaba las vacas de Gerión, a quien alude el v. 11.

7. Tras el desarrollo previo (los cuartetos en MP 67; los dos cuartetos y el primer terceto en A 52), ambos poemas se cierran con una conclusión que muy genéricamente llamaré moral. De la Plaza abandona el modo imperativo, otra de sus complicaciones formales, y pasa al tiempo futuro: tendrás, será, dejarás, serás. Explícita así la predicción, derivada de la ironía de situación, se conduce hacia un fin moralizante: "el premio que tendrás de tu fatiga / será inmortal". De modo que Hércules estampará "en columnas de diamante" su "nombre" y, "hecho dios", "el cielo" lo sostendrá a él: es que, como recuerda Ruiz de Elvira, Hércules, durante su undécimo trabajo, convence a Atlas para que "vaya a buscar las manzanas" de las Hespérides, mientras él lo sustituye "como sostén de la bóveda celeste"; Atlas lo hace y luego se niega a soportar la carga de nuevo, pero el semidiós lo engaña y consigue 
aliviarse del tremendo peso. Por su parte, Arguijo, que guía "frecuentemente" con una "intención moral" su "meditación en la historia o en los mitos" (Prieto), se refiere con Ejemplos (v. 9) - voz que tanto utiliza en sus sonetos (A 3, v. 5; A 4, v. 5; A 6, v. 14; A 9, v. 14; A 13, v. 11; A 28, v. 14; A 30, v. 13; A 32, v. 10; A 55, v. 1; A 59, v. 10) -, a quienes sufrieron "mi ilustre vencimiento". Posesivos como éste (vv. 3, 7 y 9), y el pronombre me (vv. 4 y 14), sostienen, frente a MP 67, la dicción del poema en boca del propio Hércules. En el último terceto de A 52, el héroe nota lo absurdo de narrar sus "vitorias", porque ha sido rendido por Deyanira: ese "cativo en tu prisión" alude a la cárcel de amor, que es la moralización buscada por Arguijo, en tanto que todo lector de su soneto sabía que Hércules murió por causa de su amada esposa, cuyos celos dieron en estulticia.

8. Principio de todo mal, pues, resulta el amor. La selección contrarreformista de las secuencias mitológicas es lo que implica. Porque también el deseo amoroso causó el fracaso de Apolo, vano perseguidor de Dafne: de nuevo Arguijo y Martín de la Plaza compiten en un tema que, desde Ovidio, generó no pequeña descendencia romance. Descuella en esa estirpe el soneto XIII de Garcilaso, iniciado in medias res y "modelo" para "autores posteriores", según Castro Jiménez, que de pasada menciona A23-A 24 y no atiende a MP 68. Tras recordar la comparación entre estos tres sonetos formulada por Rodríguez Marín, quien favorecía al antequerano, Marasso hizo notar la descendencia garcilasiana de MP 68. En efecto, el vi del Toledano rige la secuencia de transformación de la ninfa esquiva: "en verdes hojas vi que se tornaban / los cabellos qu'el oro escurecían"; secuencia que cierran el primer terceto con el llanto de Apolo y el segundo con una conclusión poco halagüeña para el "miserable estado" amoroso: cuanto más se llora, más crece "la causa" del llanto. Martín de la Plaza y Arguijo seleccionan las mismas dos secuencias de Garcilaso, pero añaden la antecedente: la persecución de Apolo y la carrera de Dafne. Asimismo, emplean organizaciones discursivas distintas entre sí y distantes de la garcilasiana, como asentó Lara Garrido, para quien MP 68, “entre la descripción indirecta y el discurso referido (fórmulas extremas que empleará Marino en sus sonetos Trasformazione di Dafne in Lauro y Parole d'Apollo mentre seguita Dafne) ha escogido una ruptura breve del primer tipo y una variación del comentario [...] que cerraba el soneto garcilasiano", lo que entiendo que vuelve a ser síntoma de búsqueda de renovación formal para un asunto archisabido de tan reiterado: 
MP 68: secuencias 1-2 [persecución de Apolo; transformación de Dafne]

Dafne, suelto el cabello por la espalda, cuyas hebras tremola el fresco viento, huye ligera más que el pensamiento, que aun no huella la hierba de esmeralda.

Tiñe la cara de color de gualda cuando oye cerca el enemigo aliento del dios, que forma celos del contento que goza el aire alzándole la falda.

Viendo que corre y vuela y no la alcanza, le grita: «Ninfa hermosa, pues te adoro, detente, aguarda, mira el bien que pierdes».

Mas sécasele el verde a su esperanza cuando mira las crespas hebras de oro de un laurel transformarse en hojas verdes.

\section{A 24: secuencias 1-2}

[persecución de Apolo;

transformación de Dafne]

Con presto curso y con veloz denuedo sigue Apolo la hija de Peneo; hurtó el uno las alas al deseo y al otro le prestó sus pies el miedo.

«¿Por qué te alejas, si alcanzarte puedo», le dijo, «de mi amor oh digno empleo? ¿Piensas, cual Aretusa de su Alfeo, huir de mí, que al vago viento ecedo?»

Alentó la carrera y, ya rendida, cuidó tener de Dafne la dureza: tanto se le acercó el amante ciego.

Mas del piadoso padre socorrida, trocando en árbol la mortal belleza, burló sus brazos y avivó su fuego.

Como al tratar de Hércules, Martín de la Plaza opta por la dificultad, que ahora implica no sólo retorcimiento sintáctico ("huye ligera más que el pensamiento"), sino también rebusca léxica (tremola, gualda) y preciosismo, que si en MP 67 aparecía en columnas de diamante, ahora resalta en hierba de esmeralda, con signo de un Martín de la Plaza en quien "la pareja falda-esmeralda hace bastante gasto" (Carreira). La artificiosidad que guía tal dificultad es asimismo evidente en la pictográfica diagonal metamórfica que desde Dafne alcanza a hojas verdes, o en el v. 9 y el inicio del 10, construidos casi exclusivamente con verbos: "Viendo que corre y vuela y no la alcanza, / le grita".

9. Si un soneto empezaba con la palabra clave Dafne, poca duda habría de que apenas pudiera decir algo nuevo sobre el asunto. De hecho, MP 68 recupera la argumentación del ver de Garcilaso: "mira las crespas hebras de oro / de un laurel transformarse en hojas verdes". Pero introduce un irónico distanciamiento respecto de la historia tantas veces narrada: Apolo siente celos "del contento / que goza el aire alzándole la falda" a Dafne. Aunque ya en Met., I, 500-502, sin referencia alguna a los celos, Apolo laudat digitosque manusque / bracchiaque et nudos media plus parte lacertos: / siqua latent, meliora putat, lo que en 1589 había traducido Sánchez de Viana: “Alaba aquellos brazos elegantes, / más que hasta la mitad arrezagados, / divinas manos, dedos semejantes. // Imagina los miembros ocultados, / y juzga ser mejores" (I, vv. 800-804). Con la innovación formal se alinea, en búsqueda de distinción, el irónico escepticismo sobre la materia; no otra es la síntesis a la que también se llegaría si de hablar de humanismo contrarreformista hubiera que ocuparse. Quevedo abismará distanciamientos cuando aconseje burlescamente a Apolo con el ejemplo de Dánae, 
nombre aludido y cuya fonética tan próxima está a la de Dafne: “levantóse las faldas la doncella / por recogerle en lluvia de dinero".

10. Dos detalles ovidianos dicen de la cercanía de los tratamientos dados por Arguijo y Martín de la Plaza, que fue más fiel al original: "el enemigo aliento" que Dafne siente a sus espaldas (MP 68) coincide con la constatación de A 24: "tanto se le acercó el amante ciego". Ambos remiten a Met., I, 541-542, donde Apolo requiemque negat tergoque fugacis / inminet et crinem sparsum ceruicibus adflat (traducción de 1589: "Y sin dejar holgar la que ha seguido, / la tiene casi asida, resoplando / el oro en sus espaldas esparcido" [I, 875-876]). Además, el dios pretende convencer a la ninfa, con discurso directo, de que es mejor que se detenga, por "el bien que pierdes" (MP 68) o, más práctico, porque "al vago viento ecedo" (A 24). Apolo había gritado a la ninfa que amor est mihi causa sequendi! y, preocupado por si ella se caía, añadió: Nescis, temeraria, nescis, / quem fugias, ideoque fugis (Met., I, 507 y 514-515). Sánchez de Viana arromanzó así: "Amor me da espuelas a seguirte" y "Por no saber quién soy y mi manera, / huyes de mí con tanta ligereza" (I, 815 y 827-828). Martín de la Plaza, pues, está más cerca de este fragmento, mientras que Arguijo se aproxima a Met., I, 540-541: Qui tamen insequitur, pennis adiutus amoris, / ocior est ("Mas el que va siguiendo sin mudanza, / de las alas de Amor favorecido, / es más ligero, y casi ya la alcanza" [Sánchez de Viana, I, 871-873]). En cuanto a la secuencia de la transformación, en MP 68 y A 24 se reserva, tras la adversativa Mas, para el último terceto, que Arguijo cierra con bimembración: "burló sus brazos y avivó su fuego", algo muy típico en quien emplea también artificios como el paralelismo ("hurtó el uno las alas al deseo / y al otro le prestó sus pies el miedo") que Vranich aproximó a Met., I, 539: his spe celer, illa temore ("a él hacía ligero la esperanza, / a ella hacía el temor ir presurosa" [Sánchez de Viana, I, 869-870]). Menos afortunado resulta este curioso comentario del mismo Vranich: "La ninfa ciertamente se halla sin aliento, y a esto se debe que en el soneto no pronuncie ni una palabra". El mecanicismo crítico (o formalismo extremado) es lo que tiene.

11. Como Garcilaso había clausurado su soneto XIII con una suerte de moralización, lo lógico es que MP 68 y A 24, que más o menos tratan de separarse de su antecedente, carezcan de ésta. También en A 23 "Arguijo tuvo muy en cuenta el soneto de Garcilaso, tanto para evitar el mismo tema, como para no imitar su estilo", por lo que "no toca la transformación de Dafne", según Vranich, pues - como explicó Prietoel poeta sevillano logra la "novedad" desatendiendo los tratamientos renacentistas y volviendo a los textos clásicos: aquí, lejos del XIII de Garcilaso, ofrece "la voz de su personaje". El caso es que A 23 conduce el lamento de Apolo en discurso directo, y lo cohesiona en torno al concepto 'memoria': 


\author{
A 23: secuencia 3 \\ [lamento de Apolo] \\ «Vitorioso laurel, Dafnes esquiva, \\ en cuyas verdes hojas la memoria \\ de tu rigor y de mi triste historia \\ quiere el Amor qu'eternamente viva; \\ "l'antigua palma y l'abundosa oliva \\ a ti de hoy más inclinarán su gloria; \\ tú ceñirás, en premio de vitoria, \\ del fuerte vencedor la frente altiva», \\ dijo el burlado Cintio, y a la dura \\ corteza asido, la contempla y luego \\ repite: «¡Dafnes fiera, mármol frío!, \\ »del rayo ardiente vivirás segura, \\ que no es bien que consienta ajeno fuego \\ quien pudo resistir al fuego mío».
}

Seguramente las palabras clave con que principia el soneto (Vitorioso laurel) han generado el concepto 'recuerdo', porque en numerosos poemas del Siglo de Oro ciertos lexemas automatizaron la referencia encubierta a la significación de personajes míticos, como Prometeo (hurtar y fuego), Tántalo, Ixión o igualmente Prometeo (tormento), Venus (espuma), Ícaro y Faetón (osar, atrevimiento), y, por supuesto, Dafne y Apolo (laurel). El caso es que las "verdes hojas" de Garcilaso y MP 68, no sólo quedarán como "memoria" del "rigor" de la ninfa y de "mi triste historia", sino que son a su vez transformadas en signo de cualquier "fuerte vencedor", en virtud de las palabras de Apolo: Tu ducibus laetis aderis, cum laeta Triumphum / uox canet (Met., I, 560-561), es decir, "serás señal honrosa de victoria / al capitán triunfante, y suma gloria" (Sánchez de Viana, I, 914-915).

12. Los dos cuartetos de A 23 transitan la isotopía que desde Vitorioso laurel pasa por eternamente viva, y que continúa la serie de cuatro palabras rima; en éstas, y como ocurre en ocasiones, la isotopía coincide con la isofonía, hasta hacer tambalearse la teoría de la arbitrariedad del signo lingüístico: memoria, historia, gloria, vitoria. Mi análisis no tiene por qué compartir el de Vranich, para quien A 23, con sus 42 íes, recurre a este "sonido largo y prolongado, con el cual aun en la vida diaria solemos expresar aflicción"; pero si fuese largo y prolongado, ¿cómo entender, por ejemplo, el diptongo de Cintio, "nombre que el poeta da a Apolo", y que "contiene dos" íes? Por lo demás, A 23 pretende clausurarse, como el soneto XIII de Garcilaso y como MP 68, con una agudeza. Otra cosa es que ni Arguijo ni Martín de la Plaza acertasen con ella: el cierre-predicción de Apolo en A 23 queda "algo deslucido" (Vranich) y que a Apolo "sécasele el verde a su esperanza" al contemplar la transformación de la ninfa “en hojas verdes" (MP 68) es, según Lara Garrido, “equívoco poco afortunado”, pero lo importante es la descendencia garcilasiana del intento, que con toda razón aprecia este último crítico. 
13. Ya que estamos en la ejemplificación moral de los males a que conduce el amor, vayamos del "burlado Cintio" (A 23, v. 9) al "traidor Teseo" (A 39, v. 11), que no habría podido matar al Minotauro sin la ayuda de Ariadna, a quien luego abandonó en la isla de Naxos:

\section{A 39: secuencia 2}

[lamento de Ariadna]

«¿A quién me quejaré del cruel engaño, árboles mudos, en mi triste duelo?

Sordo mar, tierra extraña, nuevo cielo... ¡Fingido amor, costoso desengaño!

»Huye el pérfido autor de tanto daño, y quedo sola en peregrino suelo, do no espero a mis lágrimas consuelo, que no permite alivio mal tamaño.

»Dioses, si entre vosotros hizo alguno de un desamor ingrato amarga prueba, vengadme, os ruego, del traidor Teseo.»

Tal se queja Ariadna en importuno lamento al cielo, y entretanto lleva el mar su llanto, el viento su deseo.

\section{MP 65: secuencias 1-2}

\section{[huida de Teseo; lamento de Ariadna]}

La vela de traición y viento llena, con la vista cansada y el deseo, sigue Arïadna, del traidor Teseo, desde la playa que a su llanto suena.

Sus hebras de oro, de piedad ajena, injuria, y deja en su dorado empleo al aire rico y al azul Nereo con perlas que llorando da al arena.

«Vuelve, ingrato - le dice-, y al engaño con que el honor me quitas no le aumentes la soledad de estos peñascos fríos.

»Mas jtriste yo! que esfuerzo el propio daño, pues que te dan, con que de mí te ausentes, el viento en popa los suspiros míos».

El amor que implica el discurso directo de Ariadna conlleva un tema moral, el "de la ingratitud", según Vranich, para quien Arguijo se basa en "precedentes clásicos bien digeridos": Ovidio y Catulo, que trataron el lamento de Ariadna al ver las naves de su amado partir. (Arcaz Pozo detectó el catulianismo hispalense, y más en concreto el de Rioja y Caro.) Teseo y Ariadna son en A 39 dos isotopías opuestas de continuo: los segundos hemistiquios de los versos 1 y 2 exponen la causa (cruel engaño) y la consecuencia (triste duelo) del discurso de Ariadna, lo que retorna, recolectado, en el verso 4: “¡Fingido amor, costoso desengaño!”. En el segundo cuarteto, el estatismo de la heroína (quedo sola) contrasta con el alejarse de Teseo: "Huye el pérfido autor de tanto daño". A 39 - que como A 52 practica el "detener" "un momento" del "movimiento secuencial de una lectura visualizada por la imaginación" (Prieto) - quiebra la argumentación del inicio, el lamento de Ariadna, con el último terceto, compuesto en tercera persona; frente a éste, en el primero invoca la protagonista a los dioses - como la Hécuba de MP 59- para solicitar su venganza.

14. De la Plaza, que "sin duda conocía el soneto de Arguijo", asemejó al "perfecto" bimembre final de A 39 - “el mar su llanto, el viento su deseo", parte de "uno de los flamantes remates" arguijiano - el v. 7 de MP 65: "al aire rico y al azul Nereo" (Vranich). Además, MP 65 invierte (relato en tercera persona [cuartetos]; lamento de Ariadna [tercetos]) "el diseño estructural" de A 39, pero mantiene "el 
sintagma «del traidor Teseo»" (Lara Garrido). De hecho, MP 65 amplía A 39 con una secuencia precedente, tal como Martín de la Plaza y Arguijo hicieron respecto al XIII de Garcilaso. Este añadido muestra en MP 65 la dependencia de Ovidio, Her., X, 1550 en "los detalles descriptivos (la llamada «in litore» [v. 4] o el arrancar los cabellos acompañando al llanto [vv. 5-8]), y sobre todo dos huellas léxicas: la duda entre visión real y deseada («aut vidi aut acie tamquam vidisse putarem») [v. 2] y la frialdad de las peñas («in saxo frigida sedi») [v. 11]”, como señala Lara Garrido, quien está de acuerdo con que MP 65 se compuso "teniendo en cuenta" A 39, "uno de los más famosos de Juan de Arguijo". Extremando la maniera - algo nuevo había que hacer-, MP 65 complica la sintaxis y espejea sus dos versos iniciales ("La vela de traición y viento llena, / con la vista cansada y el deseo") en los dos endecasílabos finales, en los que de nuevo se percibe la tendencia de Martín de la Plaza a cerrar sus sonetos con una agudeza, aquí hiperbólica: "pues que te dan, con que de mí te ausentes, / el viento en popa los suspiros míos". Teseo es movimiento, vale decir, viento en popa a toda vela; Ariadna, estatismo, o sea, vista-deseo y suspiros. El viejo mito ha sido nuevamente explorado y explotado.

\section{EN EL PRINCIPIO FUE LA GUERRA DE TROYA}

15. El imaginario occidental registra como recuerdo literario primero el relato homérico, arquetipo de una memoria heroica al que siguieron consecuencias sin cuento; la principal, la fundación de Roma. De las ruinas de Ilión surgirían los cimientos de otra ciudad que se quiso eterna, cuando eterno sólo pareciera el reciclaje de la muerte y de la vida, de imperios y batallas, de las piedras y la poesía. Agente del reciclaje de Troya en Roma, Eneas obedece a un designio divino muy superior a cualquier gesto humano, incluidos sean el noble de la hospitalidad o el telúrico del amor. Es evidente que el lamento de la traicionada Ariadna se relaciona con el de la engañada Dido. Espejeando la historia de Teseo y Ariadna, la relación entre Eneas y Dido dio para mucho: hasta para abominar del pío troyano y considerar, al margen de la voluntad de los dioses, que la reina no merecía el trato recibido. Al trazar la defensa española y antivirgiliana de Dido, Lida de Malkiel trató sobre A 45 y A 1, poema éste que relacionó con el romance 485 de la colección de Durán y con la alusión a Dido y Eneas que hay en el soneto de Arguijo en alabanza de El peregrino... de Lope, y del que comentó el contraste entre el fuego de Ilión y el amoroso. En efecto, A 1 emplea la imagen con que presenta Eneida, IV, 1-2 el "ciego ardor («caeco carpitur igne») de Dido", "contrastándola con la del incendio de Troya", como en A 45 (Vranich). Es una "agudeza basada en el contraste", "un común procedimiento del epigrama de Marcial", como indica Cristóbal, para quien Arguijo, en sonetos como estos dos, sigue temáticamente la Eneida y formalmente a Marcial y su "estructura bipartita del 
epigrama, con exposición y glosa de un acontecimiento". Por su parte, A 45, "uno de los más espléndidos ejemplos castellanos de conversión del epigrama latino en soneto" (Prieto), sintetiza Eneida, I, 340-368, incluso “con proyección del léxico y de ciertos conceptos virgilianos" (Cristóbal).

16. Como señalé, Arguijo inauguró con A 45 las Flores de poetas ilustres de Espinosa. Seguramente estamos ante la cabeza de la serie de sonetos que, en el sevillano y en Martín de la Plaza, recorren cuatro secuencias esenciales en la historia de Dido y Eneas:

\section{A 45: secuencias 1-4}

[huida de Tiro; enamoramiento de Dido; engaño de Eneas; muerte de Dido]

La tirana codicia del hermano, impia ocasión del fin de tu Siqueo, huiste fiel por el airado Egeo, Elisa, hasta el término africano, donde reliquias del ardor troyano encendieron en ti nuevo deseo, y entregaste en infausto himeneo al teucro engañador la fe y la mano.

Despreciaste, en tu daño presurosa, la merecida fama que destruyes con el engaño que ostinada quieres.

¡Oh en ambas bodas poco venturosa! Muriendo el uno, perseguida huyes; huyendo el otro, desdeñada mueres.

\section{A 1: secuencia 2}

[relato de Eneas y enamoramiento de Dido]

De la fenisa reina importunado, el teucro huésped le contaba el duro estrago que asoló el troyano muro y echó por tierra el Ilïón sagrado.

Contaba la traición y no esperado engaño de Sinón, falso y perjuro; el derramado fuego, el humo oscuro, y Anquises en sus hombros reservado.

Contó la tempestad qu'embravecida, causó a sus naves lamentable daño, y de Juno el rigor no satisfecho.

Y mientras Dido escucha enternecida las griegas armas y el incendio extraño, otro nuevo y mayor le abrasa el pecho.

Artífice supremo, según constató el soneto sobre Hércules, Arguijo resume en el breve espacio de A 45 las cuatro secuencias básicas que una enciclopedia emplearía, en la entrada Dido, para sintetizar la biografía de la reina de Cartago. Y lo hace mediante la frecuente alusión cultista, esperable cuando el poeta sabe que los receptores lo saben todo sobre su asunto. En el cuarteto inicial o secuencia 1, Pigmalión, el "hermano", mata al esposo de Dido (el "fin de tu Siqueo"), lo que provoca que "Elisa" Dido escape de Tiro "por el airado Egeo" y funde una nueva ciudad en Libia, "el término africano". En el otro cuarteto o secuencia 2, Eneas, también huido, pero de Ilión, según recuerda ("reliquias del ardor troyano") en la corte cartaginesa, enamora a la reina ("encendieron en ti nuevo deseo"), que yace con él "en infausto himeneo", antes de ser traicionada en la secuencia 3 por el "teucro engañador". Si A 45 explota, como A 1 y A 23, la trivial ambivalencia de, respectivamente, fuego, incendio y ardor, que en los tres poemas tienen como referentes el término real y el metáforico de amor, A 45 y A 39 comparten la designación de sus protagonistas masculinos: teucro engañador-traidor 
Teseo. El drama de la poesía neoclásico-contrarreformista estriba, en efecto, en que, pretendiendo rehuirlo, el abismo de la automatización siempre se encuentra a los pies del poeta. Es un abismo que, para este caso, salvará el bribón troyano de Quevedo. (Lida de Malkiel atendió a éste y al otro tratamiento quevedesco y burlesco del asunto, así como a los de Alcázar y el Quijote, del mismo jaez.)

17. A 45 concluye con la muerte de Dido desdeñada, formando una glosa del anónimo dístico (Infelix Dido, nulli bene nupta marito / hoc pereunte, fugis, hoc fugientes, perit) que "deplora" "la inaudita mala suerte" de la reina: "forzada a huir de Fenicia cuando murió el primer marido (Siqueo), decidió morir en Cartago cuando huyó el segundo (Eneas)", según aprecia Alatorre, para quien A 45 "traduce" el dístico "en los tres últimos versos; pero el curso todo del soneto está sabiamente orientado hacia este final". Además, la glosa arguijiana transfiere "el juego de palabras fugientes-fugis", conjuntando bimembración, paralelismo morfo-estructural y "perfecta distribución de acentos" (Vranich). Si Arguijo coincidió con Herrera concurriendo en el epigrama Infelix Dido y en la estampa de Alejandro ante el sepulcro de Aquiles (Prieto), MP 57 seguirá la segunda de las "dos variantes temáticas" surgidas "como paráfrasis del «Dulces exuviae...» virgiliano, o de su derivación en el epigrama Infelix Dido": "la de las tristes memorias" "y la de aquellas para las que se solicita el olvido" (Lara Garrido).

18. A 1 se centra en dos aspectos de la segunda secuencia. Los pretéritos contaba (vv. 2 y 5) y contó (v. 9) muestran a Eneas narrando la destrucción de Troya (vv. 3-4), aludiendo al caballo de madera (5-6) y refiriéndose al rescate de su padre Anquises en medio del incendio (7-8) y a la tempestad que le llevó a Cartago (9-11). Siendo "la base estructural de este poema" "la repetición anafórica de «contar» en cada una de las tres primeras estrofas, y el reiterado empleo de la conjunción «y» con la cual se hilvana lo relatado", Vranich presenta A 1 forjado según la "nítida división en tres partes" de Eneida, II (cuartetos), y resumiendo respectivamente Eneida, I y IV en los tercetos. Por lo demás, entiendo que A 1 responde a un binarismo estructural desequilibrado que se va comprobando habitual en Arguijo, pues ahora el segundo terceto quiebra el curso anterior al mostrar la recepción por Dido del relato del troyano, cuyas palabras, pasadas y en pasado, contrastan con el tiempo presente regido por el escucha del verso 12. El cambio de los tiempos verbales principales empleados por el narrador, pone de relieve el asunto de esta glosa: el enamoramiento de Dido.

19. No es improbable que el alarde sintetizador de los cuartetos y glosador de los tercetos precipitara la elección de A 45 como pórtico para la antología de Espinosa. En todo caso, su selección lo propuso como modelo digno de imitación. A ello se pondría Martín de la Plaza, si bien partiendo de Camoens: recordando a Michaëlis, para quien MP 56 es versión no muy libre de "Os vestidos Elisa revolvía...", Lara Garrido afirma 
que De la Plaza “casi traduce el segundo cuarteto («Entr'eles a fermosa espada vía / que instrumento foi da triste historia / e como quem de si tinha a victória / falando só com ela, assi dizia») y varía, cambiando de rimas, la alocución de los tercetos, que en Camoens dibuja el contraste entre la «fermosa» espada que queda en recuerdo y la tristeza presente"; de manera que MP 56 "forma parte incuestionable del canon camoniano, aunque se difundió en diferentes versiones, algunas anónimas":

\section{MP 56: secuencia 4a} [desesperación de Dido]

Elisa los vestidos revolvía del teucro engañador, y su memoria en ellos, la que tuvo dulce gloria cuando su hado quiso y Dios quería.

La espada entre las prendas relucía que fue instrumento de funesta historia, y como quien le niega tal victoria la asió del puño y con furor decía:

«Crüel espada, si el traidor troyano huyendo encomendó a tu punta fuerte la ejecución de mi mortal sentencia,

contra mi vida te quedaste en vano, que para darle gusto y darme muerte basta el dolor que me dejó su ausencia».

\section{MP 57: secuencia $4 b$} [queja y muerte de Dido] «Memorias tristes de la dulce gloria que me quitó fortuna lisonjera, dejadme un hora descansar siquiera, que vencer a quien muere no es victoria.

»No fatiguéis al alma con la historia de aquel pasado bien que nunca fuera, $\mathrm{y}$, si fue, no pasara o no tuviera para que me atormente su memoria.

"Mas ya es tiempo que os cubra eterno olvido, tristes memorias, pues que se ha olvidado de mí el tirano por quien muero ausente».

Dijo llorando la sidonia Dido sobre las prendas de su bien pasado, y muriendo acabó su mal presente.

Ser portavoz de un poeta-modelo anterior es otra faceta de la reescritura del pasado que caracteriza, en cuanto enorme palimpsesto, a la poesía de la Contrarreforma. Aprovecho la fructífera complementariedad de dos reseñas para recordar este rasgo: "Las traducciones son homenajes de admiración a los poetas traducidos, lo mismo que las reminiscencias" (Alatorre), de modo que para Martín de la Plaza vale el aserto de que "la musa que más inspiró [...] podía llamarse Intertextualidad", y "en eso consiste su extremado manierismo" (Carreira). MP 56 amplía por delante la secuencia 4, haciendo que Dido, según el narrador de los cuartetos, revuelva en "su memoria" y "los vestidos" de Eneas, a quien, en los pasos de A 45, se llama teucro engañador y traidor troyano. En los tercetos, el antequerano vuelve a ensayar una agudeza: Dido toma la espada de Eneas, a la que increpa por innecesaria, porque para morir "basta el dolor que me dejó su ausencia".

20. También de Camoens procede el impulso para MP 57, que completa la secuencia 4 con el lamento de Dido (vv. 1-11) y con la escueta mención de su muerte (vv. 12-14). El soneto de Camoens identificado por Michaëlis como fuente de MP 57, "Doces lembranças de passada gloria...", "marca un proceso de apropiación personal (como en Garcilaso) que borra las huellas del tema clásico", según Lara Garrido, para 
quien MP 57 “reconduce el tratamiento a la materia virgiliana y por ello, salvo el último verso (que en el original portugués concluye: «o mal presente»), su imitación se reduce a las rimas gloria-vitoria y a cuatro versos: «Dexai-me repousar em paz uã hora / ... Deste passado bem que nunca fora, / ou fora, e não passara, mas ja agora / em min não pode haver mais que a memória»". La primera parte de MP 57, intercambiable con las quejas de cualquier amador desengañado de la poesía del XVI, cobra el valor de sonetoenigma, cuya intriga (¿quién o de quién habla el locutor?) se resuelve muy al final, con el Dijo... Dido que abre y cierra el v. 12. Es éste otro rasgo de la ultraconsciencia poética contrarreformista, en su ansia no de hallar nuevos argumentos, sino de renovar los consabidos: ocultarlos bajo una suspensión. El recurso llegó a ser muy del gusto de un Gracián activo lector de poetas de la Contrarreforma: “Así que consiste el artificio de ésta y otras semejanzas, en un apuntar sin explicarse del todo, que basta a ocasionar el reparo, y despertar la curiosidad en el que no lo entiende y el gusto en el que lo entiende" (Agudeza, discurso XLIX). Gracián se refiere aquí a la alusión, pero mantiene en toda su obra el elogio del enigma.

21. Retornemos a la guerra de Troya con Martín de la Plaza, tres de cuyos sonetos testimonian que estuvo dando vueltas al ciclo de Aquiles, su espíritu y su túmulo. La secuencia inicial que es MP 58 relata cómo el héroe, aunque advertido por Quirón, se dispone a morir matando. A este centauro, también preceptor de Hércules, había confiado Peleo la educación de su hijo, a quien Quirón nombró Aquiles. En la segunda secuencia, MP 59 cuenta que, obedeciendo al espíritu de su padre Aquiles, Pirro asesina a Polixena, cuya madre, Hécuba, suplica en vano. Finalmente, MP 60 muestra a Tetis llorando ante el sepulcro de su hijo.

\section{MP 58: secuencia 1}

\section{[muerte de Aquiles]}

«Corrige, altivo mozo, el pensamiento, que aunque lleve tu brazo al Asia espanto, la muerte a Héctor y la sangre a Janto, el fuego a Troya, a su ceniza el viento, »contra el que allá te aguarda fin sangriento ni valen hierbas ni aprovecha encanto», dijo el viejo Quirón, bañado en llanto, al griego Aquiles, por mudar su intento.

Mas llevó su consejo el aire vano, y del joven la nave y el deseo, alta codicia de inmortal memoria,

donde, si en flecha de cobarde mano muerto a traición, lo sepultó el Sigeo, viva quedó de su valor la gloria. 
El discurso directo de Quirón adquiere tintes admonitorios, tan caros a una predicación contrarreformista. El verbo Corrige, moralizante donde los haya, encabeza el soneto y arrastra, hasta el verso 11, la isotopía altivo mozo, mudar su intento, consejo y alta codicia. Isotopía rechazada por el pensamiento (v. 1) del propio Aquiles, y a la vez confirmada (desde la adversativa Mas que abre el primer terceto) por su actitud, decidida a alcanzar esa gloria que es palabra que cancela el poema. De manera que entre el corrige inicial y la gloria final - como en MP 68, según vimos, también aquí rige la composición el trazo de una diagonal - , MP 58, que ha sido un enigma hasta el v. 7 , vale decir, hasta su mitad, parece ofrecer al receptor las dos opciones que hubo de sopesar Aquiles.

22. El inicio ex abrupto de MP 58 es otro resultado de que el poeta trate un asunto conocido por sus futuros receptores: estaba de los dioses que Aquiles sería imprescindible para conquistar Troya, lo que en edad juvenil conllevaría su gloria, pero su muerte, su muerte, pero su gloria. De no acudir a Ilión, fallecería viejo, mas se perdería su recuerdo (Ruiz de Elvira remite a Ilíada, XVIII, 88 y ss.): eligiendo matar a Héctor, Aquiles sabe que morirá, de modo que aquí no puede funcionar la ironía de situación. Martín de la Plaza reescribe lo predicho y ya dicho, según el modo tan suyo que conocemos: suspende el curso semántico con la intriga de los vv. 1-6, resuelta cuando se descubre que es el viejo Quirón quien se dirige al griego Aquiles; complica la disposición retórica, pues en los vv. 3-4 la bimembración (luego también en el v. 6), el paralelismo y juntamente la correlación, trazan la serie, casi lógica y cronológica, muerte, sangre, fuego, ceniza; y alambica la sintaxis, mediante los hipérbatos de los vv. 5 y 10 $\mathrm{y}$, sobre todo, el muy violento del final, que se reconstruye leyendo alternativamente los vv. 12-13: [... Troya], donde, si [= 'si bien'] (12) muerto a traición (13) en [= 'con'] flecha de cobarde mano (12) lo sepultó el Sigeo (13), viva quedó la gloria de su valor (14). Sintácticamente no es más sencillo el primer terceto, que se descodifica a saltos entre el verbo explícito y el elidido, y entre la lectura horizontal y la vertical: Mas el aire vano llevó su consejo [= 'pero las palabras de Quirón se las llevó el viento'] (9) y el deseo del joven (10), [esto es, su] alta codicia de inmortal memoria (11), [llevó = 'empujó'] la nave (10) [en que se embarcó hacia Troya], donde... (12).

23. Mi interpretación descarta, pues, puntuar con coma tras joven "para suplir el verbo", según sugiere Carreira, quien añade que el v. 12 "no puede terminar en coma: difícil es que Aquiles resulte muerto en flecha, pero sepultado es imposible". Efectivamente, debe leerse en flecha de cobarde mano / muerto a traición, pero no porque sea erróneo en flecha (y reconozco no saber a cuento de qué aduce aquí Carreira lo de sepultado). El salmo XXIV del Heráclito cristiano de Quevedo autoriza la lección en flecha de MP 58: “Ve dilatar las alas poderosas / al águila real por sus hijuelos, / que encima van seguros / de muerte alada, en flecha penetrante, / las iras licenciosas / que 
amenazan ligeras a los cielos [...]". La puntuación de Blecua oscurece el sentido de este pasaje, pues sobra la coma anterior a en flecha, y después de penetrante debe ir punto. (También hay que enmendar la puntuación inmediatamente posterior.) Sucede que el sintagma en flecha de ambos textos proviene de un in + ablativo con valor instrumental, del tipo percutere in virga, 'golpear con la vara', inhabitual en el latín cristiano, pero frecuente, por influjo semítico, en el bíblico, según explicó García de la Fuente. Otra construcción extraña o latinizante hay en T 106, al que enseguida voy: “ $a$ ['con'] la mano revuelve..." (v. 2). Estando ante cultismos sintácticos, se impondría tal vez la conexión cordobesa, es decir, el que Martín de la Plaza fuese "admirador y amigo, como discípulo", de Góngora, según advirtió Marasso, o que, en fecha tan temprana como 1603, el antequerano aparezca como "el primer seguidor que tuvo Góngora" (Alatorre); pero acaso quepa aducir más bien la evidencia sociológica de que Góngora, Martín de la Plaza y Tejada son clérigos contrarreformistas familiarizados con las lecciones no sólo del latín clásico, sino también del bíblico.

24. Menos amigo, que sepamos, de componer sonetos -descartando los publicados en preliminares de libros ajenos, conocemos poco más de veinte, siete de ellos funerarios (Molina Huete) - , Tejada Páez echó su cuarto a espadas en el asunto de la muerte de Polixena, porque de lo que sí gustó fue de la materia fúnebre. T 106 inicia la segunda secuencia sobre Aquiles, cuando Pirro, su hijo, se dispone a matar a Polixena para vengarlo:

\section{T 106: secuencia 2a} [muerte de Polixena]

De oro crespo y gentil rubia melena a la mano revuelve Pirro airado, y el brazo y el estoque, en alto alzado, amenaza con muerte a Polixena.

Ella, más de valor que de ansias llena, el bello rostro en lágrimas bañado, los dioses llama; el templo ha resonado, volviéndole los ecos a su pena.

«Engáñaste, le dice, si pensares que al alma fiera de tu padre agrada ofrenda tan mortal, tan impio hecho;

que si víctima soy en tus altares tu padre matas con tu misma espada, pues que siempre vivió dentro en mi pecho». y muerto, a Polixena das la muerte».

\section{MP 59: secuencia $2 b$ [muerte de Polixena]}

Cuando aplaca de Aquiles inhumano, Pirro, el alma, con sangre que derrama de Polixena, que a los dioses clama y solicita su piedad en vano,

Hécuba esparce del cabello cano hebras al viento, y como fiera, brama; al alto Jove a la venganza llama de agravio tal, con fulminante mano.

Mas, por ver si con tierno sentimiento se mueve a compasión el mozo altivo, en estas quejas el furor convierte:

«Aquiles, de mi sangre aun hoy sediento, pues a mi Héctor me mataste, vivo,

En T 106 hay "una confrontación de fonemas ásperos (presentes sobre todo en el primer cuarteto) y suaves (en el segundo)", cuyos sonidos reflejarían, según parecer de Cotta Lobato, "los contrastes visuales de la dramática escena: la fiereza del armado guerrero griego y la delicadeza e indefensión de la doncella troyana". Más comprobable es que T 106 presenta "la misma organización discursiva" de MP 59, 
"que retoma la historia mítica precisamente en el punto en que aquí se concluye" (Lara Garrido). En efecto, las relaciones entre ambos sonetos van más allá de lo temático, hasta coincidir al menos en: 1) Pirro, que figura en MP 59 y T 106 desde el v. 2, apenas desempeña un papel instrumental; 2) mostrando un común impulso, Polixena se dirige a la divinidad: los dioses llama (T 106), a los dioses clama (MP 59); 3) Aquiles es presentado como alma fiera (T 106) e inhumano (MP 59), contraste que dice mucho de ambos poetas: mientras el afán épico de Tejada apunta a la ferocidad del guerrero, De la Plaza explora el doble sentido de una palabra que también significa 'espíritu', 'no humano' (sentido este segundo al que atiende Morata Pérez; creo que el no renunciar a los varios significados de un signo es lo que permite entender, con Marasso, a MP 59 como muestra del conceptismo del antequerano); 4) ambos textos focalizan los cabellos de los personajes femeninos, como si trataran de fijar plástica y simbólicamente la escena: el oro crespo y gentil rubia melena de Polixena - como anota Colón en la canción atribuida a Barahona, la hija de Príamo lleva el cabello suelto - es violentado por la mano de Pirro en T 106 y, en MP 59, Hécuba parece mesar su propio cabello cano; 5) la construcción es - lo indicó Lara Garrido - idéntica: en los cuartetos, Pirro se dispone al asesinato de Polixena, mientras que en los tercetos se implora piedad en un discurso directo, bien de la muchacha a su agresor (T 106), bien de Hécuba a Aquiles (MP 59), y 6) ambos poemas se cierran con una paradoja: Aquiles vive en Polixena, de modo que si Pirro la mata, matará a su padre (T 106), y Aquiles, vivo, mató a Héctor, y, muerto, va a matar a su hermana (MP 59). Demasiadas coincidencias como para no sospechar, más que una imitación, la conocida competencia de certamen poético sobre un asunto propuesto. Sabiendo que T 106 mira a un "autor admirado por Tejada", que "tiene en cuenta el relato ovidiano tal como lo recreó, en su canción De la muerte de Policena, Barahona de Soto" (Lara Garrido), la competencia tal vez partiera aquí del pie forzado de este poema de Barahona, quien seguramente, junto con Silvestre, fue el puente de Espinosa hacia el pasado del prometido (y no cumplido) padre compañero para su antología. También el contrarreformismo poético es sociología de lírica lid, justa poética, premio académico o reunión de palabras que lleva el viento y de letras que yacen en actas. Lo señaló Egido al comienzo de su exposición sobre el asunto: “Toda ocasión era buena para procurar encuentros. El humanismo se apoyaba en una impostación dialógica, exaltaba la amistad, la confianza, la reunión entre espíritus con idénticos propósitos".

25. Motivo de competencia hubo de ser asimismo el sepulcro de Aquiles. Si MP 60 trata el llanto de Tetis, con lo que vuelve a centrarse en el dolor materno por la pérdida del hijo, A 27 opta por la perspectiva del héroe que, siglos después, añora el destino de Aquiles: 
MP 60: secuencia 3

[sepulcro de Aquiles]

Adonde lava Janto el pie al Sigeo, en vez de monumento un monte encierra, muerta la lumbre, al rayo de la guerra, al invencible hijo de Peleo.

Allí quedó para inmortal empleo de su valor, pues su valor destierra con espanto al troyano, que a su tierra, ya vuelta en polvo, lo volvió el deseo.

Su pecho descuidado, golpe fuerte [clavó] de aguda si traidora flecha, que burló de las armas el encanto.

Su madre Tetis tan injusta muerte llora, gastando de dolor deshecha del mar las aguas en amargo llanto.

\section{A 27: secuencia 4}

[Alejandro Magno ante el sepulcro de Aquiles]

Sobre el sepulcro del ilustre griego, que honró con sus cenizas el Sigeo mejor que a Caria el rico mausoleo, Alejandro paró y exclamó luego: « $\mathrm{O}$ h gloria de la Grecia, claro fuego, cuya llama las sombras del Leteo no bastan a encubrir, ni su trofeo borrar podrá jamás olvido ciego!

»A ti, dichoso joven, guardó el cielo - por que eterno tu nombre al mundo fuera del gran Homero la divina historia;

»que si de aquella pluma el alto vuelo faltara, un mismo túmulo cubriera tu mortal suerte y tu inmortal memoria.»

MP 60 sitúa con precisión el enterramiento de Aquiles: “Adonde lava Janto el pie al Sigeo", es decir, en la confluencia del Janto (cfr. MP 58, v. 3) o Escamandro, río de Troya, con el promontorio Sigeo - que recurre, también en posición de rima, en MP 58, v. 11 y A 27, v. 2-, donde "en vez de monumento, un monte encierra" la tumba del héroe o, dicho perifrásticamente, del "invencible hijo de Peleo". Para Carreira, MP 60 , v. 1, "es de resonancia bien polifemática", aunque puede proceder de la égloga piscatoria de Bernardo Tasso, "La dove i bianchi pie lava il Tirreno..."; y añade este crítico: “El resto, no solo el primer terceto, está estragado: vuelta (v. 8) no tiene sentido, y gastando (v. 13), tampoco". Pero no entender un pasaje no debiera conllevar su automática catalogación como textualmente estropeado: lo que indica De la Plaza es que la tierra se convirtió (vuelta: que asegura además la bimembración del verso) en enterramiento de Aquiles, de manera que polvo será, mas tendrá sentido; en cuanto a Tetis, que era Nereida o divinidad acuática, va gastando con su llanto las aguas del mar, así que tampoco hay aquí estrago textual, pues De la Plaza dobló el signo Tetis con los significados simultáneos de 'madre de Aquiles' y 'mar', sin renunciar a ninguno, como pedía la práctica conceptista. Ese último sentido es, por cierto, el único (o exclusivo) que funciona en el segundo soneto de Martín de la Plaza a Lope de Vega, coleccionado en el Antequerano, I, núms. 85 y 242, y donde el río Guadalhorce "no da bramidos ni tributo a Tetis". No menos cultista es el giro, tan explotado por Góngora, "aguda si traidora flecha" (v. 10), que, como en MP 58, v. 12, se centra en el arma (cobarde y traición recurrían en aquel contexto) que mató a Aquiles. Y como en MP 58, que opuso la alternativa entre la gloria y la vida, ahora MP 60 contrasta esa gloria, cantada en el 
último cuarteto (inmortal, valor), con el efecto amargo que en el terceto final (dolor, llanto) provocó en Tetis, madre de Aquiles.

26. Frente a estas dos dudas de Martín de la Plaza, en A 27 opta Arguijo por la gloria y la inmortal memoria. (Este sintagma, que ocupa asimismo el segundo hemistiquio no sólo de MP 58, v. 11, sino también de «A las once mil vírgenes», v. 5, estaba en la misma posición del v. 5 de la «Canción a san Acacio», de Espinosa, tan calcada por De la Plaza; y el hexasilábico inmortal empleo de MP 60, v. 5, es semejante al inmortal deseo de A 35, v. 8, teselas ambas que de nuevo completan el segundo hemistiquio.) De manera que el altivo joven que era Aquiles en MP 58 aparece aquí como el dichoso joven cuyo nombre hizo "eterno" Homero. Es que los historiadores griegos cuentan y no paran sobre la devoción de Alejandro Magno hacia la Ilíada y, en concreto, por Aquiles, a quien homenajeó, en el Sigeo del 334, junto con los caídos griegos en la Gran Guerra. De ahí el discurso directo de Alejandro, mecanismo muy frecuente en estos sonetistas que tanto cedieron la voz a sus personajes.

\section{Al final fue tratar SObRe héroes y tUMbas}

27. Estamos ya en otra materia con la mención cultista que A 27 hace del "rico mausoleo" de "Caria". El motivo recurre en A 35, que veremos luego, y en la «Oda al Tiempo» de Andrés del Pozo, que colecciona la Poética silva: “Y es más indomable el brío / con que aviva mi deseo / que de Caria el Mausoleo / pendiente al aire vacío" (vv. 71-74). Se refiere también este poema a "los milagros de Egipto", al comparar, en otro "ejercicio de academia", el amor del yo poético con "los más grandes monumentos de la humanidad", destruidos por el tiempo (Morata Pérez). La palabra clave que emplea A 27, cenizas (v. 2; cfr. el polvo de MP 60, v. 8), conforma isotopía con su selección inicial de la voz sepulcro, de tan rica sinonimia contrarreformista. Cada poeta se decantó en este sentido por distintas opciones, en lo que Tejada mostró más variedad que Arguijo y, sobre todo, que De la Plaza: mausoleo (T 118, v. 2; A 35, v. 1; A 27, v. 3); fábrica (T 108, v. 5) y túmulo (T 106, vv. 5 y 14); tumba (T 107, v. 10); monumento (MP 60, v. 2; MP 61, v. 1; MP 62, v. 6; T 107, v. 10). Las secuencias 3 y 4 sobre Aquiles nos llevan, en efecto, a una práctica predilecta de la poesía contrarreformista: el canto sepulcral. El soneto, forma "muy apta por su brevedad para el epigrama, concentra en los epitafios una lección moral, de validez universal, extraída de una vida particular", que, aun con su "limitado mundo de ideas" (Carreira), no cabe entender como poesía de circunstancias (Lara Garrido), porque además su referente no siempre es datable, como ocurre con las víctimas de la guerra de Troya: 
$\mathrm{T} 108$

[túmulo de Héctor]

Al yelmo, espada, escudo, arnés, bocina, al pendiente blasón soberbio y fiero, inclina la cabeza, pasajero, pues Marte mismo la cabeza inclina.

Esta fábrica excelsa y peregrina encierra de las armas el lucero: Héctor su nombre fue; mas tú, primero que su nombre pronuncies, ve, camina.

No ahuyentes con él las armas griegas cuyos cuerpos rindió su invicta mano y aun no han pasado el piélago Leteo;

mas con el miedo atónitas y ciegas, aun juzgan vivo al ínclito troyano y acompañan su túmulo y trofeos.
MP 62

[túmulo de Áyax]

Aquel que la grandeza de su escudo opuso a Héctor y a escuadrones ciento (mas, antes, su valor con firme aliento, pues su invicto valor vencerlos pudo), en sueño eterno y en silencio mudo descansa en este grave monumento; pienso que llorarás su fin violento si no estás, huésped, de piedad desnudo.

Flecha de arco enemigo sacudida no le privó el vivir, ni golpe fuerte de lanza que empuñó el mejor troyano:

su propia mano se atrevió a su vida, que al invencible Telamón la muerte sólo pudiera dársela su mano.

28. Si en MP 58 Aquiles se disponía a morir matando, T 108 rinde a Héctor $(e l$ lucero, que se corresponde con la lumbre de MP 60, v. 3) un homenaje ante su tumba. El soneto evidencia la necesidad de extremar los recursos formales al tratar materias consabidas. Analizando otro poema de Tejada, Roses sintetizó el modus operandi de éste: a sus "innegables virtudes elocutivas" se oponen las "limitaciones en la invención de imágenes", de modo que "el verdadero mensaje" es "la propia disposición y formalización de los contenidos (la manera)", por lo que "el verso de Tejada" es "emblema de experimentaciones". No en vano, éste es el autor del "más interesante" "experimento métrico y formal" del Antequerano (Lara Garrido). Tan peculiar elocución arranca en T 108 nada menos que con un verso pentamembre, y por Roses sabemos que la x-membración es signo estilístico de Tejada, además de que los "objetos bélicos" mencionados en T 108, v. 1, constituyeron una de las preferencias de su selección léxica. El verso 2 queda nucleado en torno a un sustantivo del que cuelgan hasta tres adjetivos (uno como epíteto), y el primer cuarteto se cierra con la especularidad de los vv. 3-4 ("inclina la cabeza [...] / [...] la cabeza inclina"), donde se halla el núcleo oracional (v. 3), al que se subordina, mediante hipérbatos, el resto de la estructura sintáctica del cuarteto (vv. 4 y 1-2). En tan poco espacio, pues, Tejada explota varias de las posibilidades que brinda la sintaxis española, sin cuya libertad combinatoria quizá hubiera sido impensable la vanguardia contrarreformista y su búsqueda - acelerada búsqueda, como en todo vanguardismo - , de nuevos efectos expresivos. Entretanto, el vocativo pasajero es hasta ahora la única marca que asegura la identidad de T 108 como poema epitafio; a partir del demostrativo del v. 5, el soneto transita por esas pocas ideas que ofrecía el subgénero: la mención del sepulcro, la orden dada al caminante de que abandone pronto el lugar, y el recuerdo de las grandes gestas del allí enterrado. 
29. Más canónico, en este sentido, es MP 62 al tratar sobre el túmulo de Áyax Telamón: derrotado por la elocuencia de Ulises, que obtuvo las armas del fallecido Aquiles, Áyax se encoleriza, acomete a unos rebaños creyendo ser los guerreros griegos, "recupera luego la razón, y al darse cuenta de lo que ha hecho se suicida", por lo que Agamenón prohibe quemar su cadáver, así que fue "el único caído griego a quien se enterró en un féretro" (Ruiz de Elvira). MP 62 se abre con un deíctico la marca típica del epitafio - y sitúa en medio (v. 8) el no menos habitual vocativo, aquí huésped, a quien solicita su aflicción ante el suicidio del héroe, vencido por su propia mano y no por la flecha tan repetida (MP 58, MP 60) en un poeta muy dado a reiteraciones como De la Plaza; un sustantivo que, por cierto, éste aprovecha para sus experimentaciones latinizantes, si no gongorizantes; aquí, la ausencia de artículo, que desaparece también en el verso siguiente: "ni golpe fuerte". El sustantivo sin actualizador recurre con "extraordinaria frecuencia” en Góngora, según Lapesa, quien añadió que el recurso implica "interpretación metafórica de la realidad aludida" por personificación o por transformación genérica - esto último es lo que creo que cabe entender en flecha y golpe (MP 62, vv. 9 y 10) - y que, como sujeto, "las posibilidades de que el sustantivo aparezca sin actualizador son mucho más reducidas" que en otras funciones sintácticas, sobre todo el "sustantivo común no actualizado y en singular", situación "casi sistemática" en las Soledades.

30. No consideraré los sonetos epitafio por Píramo y Tisbe (A 34) y Timón de MP 61, poema "a la manera de Quevedo, pero sin la enérgica fiereza" de dicho autor, y que conecta con otro de Juan de la Cueva dedicado al mismo asunto (Marasso). Prefiero seleccionar ahora una composición que no es epicédica ni epitáfica, y casi resulta menos funeral que amorosa. Es la que Arguijo enderezó al túmulo por excelencia y antonomasia:

\section{A 35}

\section{[Artemisia y Mausolo]}

Labra Artemisia el grande Mausoleo, que los altos pirámides afrenta del egipcio soberbio y, no contenta, busca a su ilustre fe mayor trofeo.

Del tierno y casto pecho, en nuevo empleo, hacer sepulcro al muerto esposo intenta, cuyas cenizas, de su amor sedienta, bebe con ansias de inmortal deseo.

«En vano», dice, «pretendió la muerte de ti, dulce Mausolo, dividirme y en largo olvido sepultar tu gloria;

»que de su injuria puede defenderte 
mi pecho más que el bronce y mármol firme

y eternizar mi amor y tu memoria.»

Este soneto de 'amor constante más allá de la muerte' dedica - como en el quevediano al que aludo - el primer cuarteto al tema fúnebre. Artemisia, "prototipo de amor y fidelidad conyugal", erige a Mausolo, rey de Caria, "un suntuoso sepulcro" que formaría "entre las siete maravillas del mundo", pero quiso "mejor lugar" "para las cenizas" de su joven esposo fallecido, y "se las bebió" (Vranich). El segundo cuarteto alza en los poemas de Arguijo y Quevedo la rebeldía ante la muerte; además, en "Cerrar podrá mis ojos la postrera..." algo resuena el "borrar podrá jamás olvido ciego" de A 27, v. 8; por otra parte, en MP 59, v. 14, se encuentra también el pecho femenino como morada del amado muerto: "siempre vivió dentro en mi pecho". Asimismo, tanto "Cerrar podrá mis ojos..." como A 35 concluyen con la imposibilidad de que la muerte venza al amor, imposibilidad que se extiende en A 35 a la derrota de la gloria, término que vamos comprobando dilecto a Arguijo.

31. Como señalé, Tejada prefiere los sonetos funerarios a, por ejemplo, los mitológicos. Visto ya T 108, me detendré ahora en la nacionalización contrarreformista de la materia fúnebre. Si Quevedo compuso un epitafio a Viriato, que luego rehizo para dedicárselo al III duque de Osuna, muerto en 1624 (Carreira), Tejada aborda esa nacionalización con el epitafio a Viriato y el soneto epicédico por Felipe II:

T 107

[túmulo de Viriato]

Fresno nudoso y guedejosas pieles, en este pobo a Alcides consagrado, pendientes, son trofeo más honrado que coronas de palmas y laureles.

Las armas son, piadosas y crüeles, con que, la diestra y cuerpo un tiempo [armado,

Viriato se mostraba un rayo airado entre italas legiones y tropeles.

A sus huesos dio Luso esta montaña por tumba, y es pequeño monumento a la temida majestad que encierra.

A sus manos beligerosa saña no muevas, pasajero, pasa atento; no profanen tus pies tan santa tierra.

\section{T 27}

[epicedio por Felipe II]

Diote, joh monarca!, en pecho el indio el [grano

del oro, que es del mundo hidropesía, diote la perla que la concha cría y el chino su brocado más galano;

sus despojos el fuerte suelo hispano, el caballo feroz Andalucía, drogas Arabia, y rica pedrería Oriente, y sus aromas el persiano.

Diote en tributo su coral Egeo, bálsamo Siria, plata el sardo astuto, Libia marfil, Corinto metal fuerte.

Fue tu despojo el mundo y tu trofeo; él todo junto te pagó tributo, y tú lo pagas hoy sólo a la muerte.

La agrupación de T 107 y T 108 en las Flores de Calderón y en el Cancionero antequerano "no parece casual": ambos sonetos "componen" "un pequeño estudio 
sobre las posibilidades retóricas de la interpelación intradiscursiva (inicio o final) al receptor" (Lara Garrido). T 107 concentra en los tercetos los rasgos del soneto epitafio: el vocativo pasajero, a quien se recuerda la calidad sagrada del lugar que pisa; y el contraste entre el pequeño monumento y la majestad del héroe, cuyo más lejano antecedente se halla, para otro propósito, en Horacio, Epist., II, 1, 257-258: neque paroum / carmen maiestas recipit tua. Los cuartetos habían atendido a las armas de Viriato: el fresno, que "por sinécdoque se toma por la misma lanza" (Aut.), y el escudo o guedejosas pieles, que cuelgan (pendientes, como en T 108, v. 2) de "este pobo a Alcides consagrado", verso 2 que, equiparando al héroe hispano con Hércules, se hizo, desde el testimonio de 1611 (pino) hasta la variante de 1627 (pobo), más cultista y herreriano (ejemplificando con Herrera, Autoridades da a pobo, que aún no figura en Covarrubias, el valor de 'álamo blanco'). En cuanto al v. 12 (manes belígeros hazaña [1611] / manos beligerosa saña [1627]), el cambio apenas altera la sustancia herreriana del verso; de hecho, Autoridades vuelve a sustentar en el sevillano belígero, "lo mismo que guerrero [...]. Es voz puramente latina, usada más en la poesía que en la oratoria”, y no recoge beligeroso, como ningún otro diccionario académico. No cabía esperar menos cultismo herrerianista de un soneto que aprovecha la áspera musicalidad del fonema / $\mathrm{m}$ / "para realzar el tono de majestad heroica y fúnebre gravedad", sobre todo en " «tumba» y «monumento», palabras de por sí bastante evidentes en el sentido de «capaces de poner ante los ojos»": es que, con la enseñanza herreriana, "la qualitas sonorum produce, a más de la voluptas aurium, la evidentia", indica Cotta Lobato, según el cual Tejada emplea sobre todo /m/ para "manifestar connotaciones majestuosas y fúnebres" en su poesía heroica y funeraria, donde funciona "como fonema áspero", es decir, "lúgubre, oscuro, desagradable", frente a la blandura adjudicada por Herrera a las nasales. T 107 es valioso ejemplo, en sí mismo y con sus variantes, de que la poética contrarreformista andaluza arranca de Fernando de Herrera.

32. De T 27, dedicado a la muerte de Felipe II, sólo conserva testimonio la Poética silva, donde Tejada dedicó al mismo asunto la canción 76 y las liras del poema 26; de ahí el título de T 27: «El mismo autor al mismo intento». Conduciendo "hasta el límite la figura del monarca, tan sólo sometida a su humana mortalidad", el soneto "busca la acumulación, la magnificación", afirma Osuna, quien aclara el sentido de en pecho (v. 1), 'en tributo', y de hidropesía (v. 2), 'avaricia', voz ésta sobre la que añadiré que, empleada por Arguijo (afición hidrópica, epístola I, 39), generó en Quevedo libropesía o "sed insaciable del pulmón librero". T 27 justifica su valor poético engarzando, en los once primeros versos, sustantivos que, dependiendo como complementos directos del reiterado diote (vv. 1, 3 y 9), remiten al tributo suntuoso (oro, perla, brocado, caballo, drogas, coral, bálsamo, plata, marfil, metal) que varios pueblos del mundo, algunos de exóticas resonancias (indio, chino, hispano, Andalucía, Arabia, Oriente, Egeo, Siria, sardo, 
Libia, Corinto) ofrecieron, como despojo (término cuya bisemia explota Tejada en los vv. 5 y 12), al monarca, quien sólo fue menos poderoso que la muerte, voz que cierra este otro ejercicio virtuoso y virtuosista.

\section{Al final fUeron las RUinas}

33. Pasemos ya de las tumbas a las ruinas, que "han dejado de ser vistas como una presencia desaparecida y una imagen material del Destino, valor genérico en la literatura clásica", según Lara Garrido, que remonta el tema moderno a Petrarca, en quien se conjugan arqueología y patriotismo. Procediendo "de la admiración por la antigüedad clásica", dos textos de "verdadera resonancia" en España para este asunto fueron subrayados por Orozco: el opúsculo de Du Bellay, Le premier livre du antiquités de Rome, y el soneto "Superbi colli et voi sacre ruine...", de Castiglione, imitado desde Cetina, a propósito del cual resulta "significativo" que sea Andalucía el lugar donde "irrumpeel tema", pues aquí “se inicia lo barrocoy sealcanza su culminación". Discurren las ruinas en la poesía áurea por tres senderos, al decir de Orozco: a) el contemplar, que estando al principio "ligado a lo amoroso", provoca la "sensación de que lo artificial, lo artístico, se incorpora a la Naturaleza"; b) la reflexión, surgida de la "idea de ejemplo de la fuerza poderosa del tiempo", y c) la imagen "grandiosa y bella de la famosa ciudad que fué", y que subraya "la supervivencia de los valores morales o espirituales: del heroísmo, del decoro". Este esquema trimembre pudo sugerir a Vranich su ordenación trifásica del tema de las ruinas en la lírica áurea: a) imitación, singularmente de "Superbi colli...", lo que originará después la "inspiración puramente literaria" sobre Troya; b) españolización, mediante el descubrimiento, primero por "los arqueólogos", de "ruinas antiguas" propias como las de Itálica, "ejemplo de los sevillanos" seguido luego para escribir "sobre Numancia, Sagunto, Singilia [cfr. T 1980] y otros sitios menos conocidos", y c) "las ruinas de la España coetánea", que dan entrada al "sarcasmo". Sin embargo, MP 53, copiado en las Flores de Calderón, luego nada menos que tres veces en el Antequerano (núms. 62, 238 y 475) y, como señaló Blecua, con elogios en otro cartapacio (Lara Garrido), vuelve al paradigma clásico del transitado tema y por tanto no encaja con la evolución trazada por Vranich. Los poetas sevillanos ofrecieron con las ruinas "una dramatización del tiempo, comunicando belleza destruida y caducidad" (Prieto), según una "retórica común" por la que D. Alonso coligió "que se trata de un tema de academia" (Lara Garrido). En este discurrir de más de un siglo, el paradigma clásico fue nacionalizado por Herrera y Arguijo (Itálica), ampliado después en sus "sujetos temáticos" (de Numancia a Calatrava la Vieja), reducido como "marco de referencia ejemplificadora" y finalmente hecho desaparecer (de Medrano a Quirós), y hasta adaptado para provocar la risa sobre las ruinas, según Lara Garrido, que incide en la evolución de un paradigma compuesto y progresivamente cargado de distintos 
significados sobre los restos saguntinos. Paradigma que, como señaló Siles, se proyecta hasta la Ilustración.

34. Martín de la Plaza y Arguijo echaron su cuarto a espadas en el asunto, al que dedicó el sevillano cuatro sonetos: A 2, sobre Cartago, Numancia y Sagunto; A 3, sobre Cartago; A 4, sobre Troya, y A 66, sobre Itálica. Cabello Porras relacionó los tratamientos de las ruinas en Arguijo y Herrera, y sintetizó los distintos significados de A 2-4 y A 66, subrayando el "enfoque bastante novedoso" de este último:

\section{MP 53}

\section{[ruinas de Roma]}

Peregrino que en medio de ella, atento, buscas a Roma, y de la ya señora del orbe no hallas rastro, mira y llora de sus muros por tierra el fundamento.

Arcos, termas, teatros, cuyo asiento cubre hierba, esto es Roma; advierte ahora cómo, aunque muerta, espira vencedora las amenazas de su antiguo aliento.

Triunfó del mundo y, por que no quedara algo en él por vencer, vencióse y yace, quedando el Tíber que su gloria hereda.

De la fortuna en el poder repara: aquella que era firme se deshace, $\mathrm{y}$ aqueste que se mueve firme queda.

\section{A 66}

[ruinas de Itálica]

Ésta a la rubia Ceres consagrada parte fecunda de la madre tierra, que el sustento común al orbe encierra de tanta espiga en la preñez dorada, fue ciudad al comercio dedicada, que la quietud y la verdad destierra; duro después teatro de la guerra, que toda en sangre la dejó bañada.

El primitivo asunto restaurado gracias rinde en el fruto repetido al circular precepto de los meses.

También, siéndole el tiempo agradecido, no más yerro la hiera que el arado, no más peso la oprima que sus mieses.

Derivando su atractivo par victa-victrix de Lucano (Siles), De Roma (1552), el epigrama de Janus Vitalis caracterizado por “la perfecta ordenación retórica [...] en torno al doblete victa-victrix, el tono apelativo directo con que expresa el extrañamiento del contemplador y el concepto ingenioso de oponer el movimiento perdurable a la inmovilidad condenada de las ruinas", fue "modelo directo" de Du Bellay, MP 53 y Quevedo (Lara Garrido). Con MP 53, "acorde" con dicha "imagen neorrenacentista", "no cabe adaptación más imantada por el atractivo retórico" de De Roma, pues De la Plaza "centra su composición" en el doblete victa-victrix, "mantiene a la Fortuna como causante de la destrucción y asigna a las aguas (Tibre) la calidad de conservar la gloria desaparecida" (Lara Garrido).

35. La evidente lección moral derivada de las ruinas fue sumamente relevante para poetas contrarreformistas. Es que este asunto, que para tanto dio, se cargó también con la idea de la fe asociada a la vanitas vanitatum (Lara Garrido), como veremos que ocurre en el terceto final de T 1980. No consideraré siquiera el remate paradójico de la traducción de MP 53, cuyo “De la Fortuna en el poder repara”, trasunto del Disce hinc possit Fortuna de Vitalis, es admonición dirigida al peregrino que fuerza a la dicción 
en segunda persona. Pero recordaré que A 66 participa de "la visión pintoresca de los elementos vegetales y zoomórficos invadiendo el ámbito de lo que fue dignidad y riqueza", según Lara Garrido, que remonta dicha visión no a Caro, como es habitual en la crítica, sino a Sannazaro. Su cierre paralelístico implica la asunción de ese estado natural que en mucho supera a la mentira del comercio y a la guerra, actividades humanas que Itálica conoció cuando viva. El deíctico inicial, propio de la poesía funeraria, haría pensar a cualquier receptor contemporáneo en la muerte, y sobre ella versa el poema de Arguijo; pero es una muerte que ha dado plenitud, porque, destruida la ciudad, el "circular precepto de los meses" se ha impuesto con el fruto repetido del arado: ya Vranich advirtió esta "original e inesperada" "reacción" ante las ruinas de Itálica. Sobre esa circularidad natural (el ciclo de la vida) se estructura A 66, que parte de Ceres (v. 1), pasa por la centrada (v. 9) restauración del primitivo asunto y desemboca en mieses (v. 14), confinando a la ciudad a un mero cuarteto encabezado por un fue que es el pasado más pretérito y rotundo que conjugar puede el español.

36. Tejada, que en T101 alzara palabras que aboliesen el tiempo, que lo conjuraran para apuntalar la Alhambra contra futuras ruinas, llora en T 1980 la desaparecida Singilia, asunto sobre el que - como recuerda Vranich - también se ejercitó Juan Bautista de Mesa en un poema coleccionado en las Flores de Calderón:

T 1980

[ruinas de Singilia]

Collado enhiesto do su furia inclina de Marte horrendo la sangrienta espada: oh gran Singilia al suelo ya arrasada, de quien sólo nos queda la ruïna.

Tanta grandeza de memoria digna ¡ay, cómo está del tiempo atropellada!, y la que fue temida y respetada, ultrajada de gente peregrina.

Viendo sus edificios ya por tierra, arcos, muros, teatro, templo y baño, admiro del Altísimo el gobierno,

y que viendo darte el tiempo guerra, hasta triunfar de ti, pueda el engaño persuadir al soberbio que es eterno.

Para la Alhambra pidió T 101 que "perdone el tiempo vuestra gran belleza", pues Tejada sabía (“¡ay, cómo está del tiempo atropellada!”, T 1980, v. 6) lo que se hizo de Singilia mucho antes de que surgiera su Antequera; por eso se encuentra lejos de A 66 y próximo a MP 53. De hecho, el pentamembre de T 1980, v. 10 (“arcos, muros, teatro, templo y baño"), no sólo ejercita la habitual x-membración tejadiana, 
perceptible en T 101, vv. 2 ("puntas, remates, chapiteles"), 13 ("estanques, jaspes, pórfidos y fuentes") y, sobre todo, 5 ("arcos, colunas, frisos, pedestales"), sino que concierta con MP 53, vv. 5-6: “Arcos, termas, teatros, cuyo asiento...". Los dos poetas sitúan la voz teatro en la misma posición versal, en las sílabas $5^{\mathrm{a}}{ }^{-} 7^{\mathrm{a}}$, memoria de una vida que fue en Roma y Singilia, mientras que Arguijo la colocó también allí - como señaló Vranich -, pero desdibujando su significado ("duro después teatro de la guerra" [A 66, v. 7]), porque a él no le parecía mal que Itálica hubiera dado en campo, mientras que a Martín de la Plaza y, sobre todo, a Tejada, les espanta la desaparición de la antigua urbe. Así se explica el horrendo de T 1980, v. 2: "Tejada suele asociar continuamente ciertas palabras con la idea de asperitas apoyándose en la unión que presentan entre forma y significado", como "la palabra horror con todos sus derivados, desperdigada aquí y allá por todos sus poemas" (Cotta Lobato). El racionero de Granada aprovecha el caso para "la vehiculación de doctrinal cristiano" (Lara Garrido), neutralizada hasta ahora en la enseñanza moral de todos los sonetos aquí revisados: “admiro del Altísimo el gobierno". T 1980 remite además a la "fiebre arqueológica" por la que Antequera vive la "búsqueda y exaltación de los orígenes ilustres en las ruinas de Anticaria, Nescania y Singilia", cuyas piedras se reciclan "en las nuevas construcciones" de la segunda mitad del XVI, “y sobre todo en la simbólica arquitectura del Arco de los Gigantes”, en el que, desde su alzado en 1585, “se integraban, junto a las figuras de Hércules y la Fama y otras estatuas y lápidas encontradas", contemporáneos epigramas neolatinos (Lara Garrido).

\section{EN EL FIN, EL PRINCIPIO}

37. Con el Arco de los Gigantes volvemos al Hércules cantado por Martín de la Plaza y revisado, hace ya tanto tiempo, en lo que fue inicio de estas páginas. Piedras y poesía: el peso de la materia clásica, legada y repetida, era, por decirlo en latín, grave. Soportarlo, para que no diese en ruinas, una responsabilidad científica, no romancista, que Arguijo asume con cuidado y exacto detallismo de orfebre, Tejada Páez con gesto circunspecto y altisonante que enseguida quedará, si experimentador, un no sé qué de antiguo, y Martín de la Plaza con la inteligencia incisiva, y por tanto complicadora, del traductor que a recrear no renuncia. Si entre ellos andaba Góngora, dispuesto para generar la nueva, por latinizante, poesía, en el horizonte se barruntaba la carcajada, quevedesca y desmitificadora, síntoma del atlántico cansancio que comportaba sostener, pareciera que desde siempre, el universo de una ya tan amplia cultura. 


\section{NOTAS BIBLIOGRÁFICAS Y COMPLEMENTARIAS}

38. Obras de referencia en este trabajo han sido, además del Diccionario de autoridades ${ }^{2}$, las de Prieto $^{3}$ y Ruiz de Elvira ${ }^{4}$. Dos excelentes bibliografías compilan el panorama de la pervivencia en nuestras letras de los mitos y de los clásicos latinos 5 .

39. Para el asunto de la poesía como ciencia en relación con Cervantes y el Quijote $(\S 1)^{6}$, habrá que considerar asimismo las funciones de los versos en esta novela ${ }^{7}$, la progresiva decantación cervantina por el modelo herreriano y - para lo que aquí me interesa - la participación de Tejada y Arguijo en dicho paradigma ${ }^{8}$. En relación con lo cual atiendo a la dialéctica, anacrónica por romántica, entre técnica y creación $(\S 4)^{9}$,

2 Reeditado por la Academia (http://www.rae.es) en el Nuevo tesoro lexicográfico de la lengua española.

3 A. Prieto, La poesía española del siglo XVI, Madrid, Cátedra, 1984-1987, vol. II: sobre Arguijo como mecenas (§ 2), p. 456; en cuanto a su "dirección herreriana" (§§ 2 y 39), extremaría "la consideración de la poesía como ciencia, tan medida por Herrera" (pp. 538 y 536); sobre su vertiente moralizadora ( 7 ) y su regreso a los clásicos (§ 11), pp. 540 y 542-543, respectivamente.

4 A. Ruiz de Elvira, Mitología clásica [1975], Madrid, Gredos, 2000². Sobre Hércules (§ 5), pp. 207-218, 255 y 251-256 (y tengo en cuenta las pp. 250-251, 231 y 237 para descifrar las alusiones de MP 67 y A 52); para las diez más dos gestas de Hércules, pp. 211 y 217-239, con recuerdo de la lista incompleta de trabajos en Met., IX, 182-199. Para Aquiles (\$§ 21 y 22), pp. 343-344 y 344-347, y para las precisiones geográficas sobre su sepulcro (§ 25), pp. 387-388; Higinio, fab. 110, relaciona la muerte de Aquiles con su amor por Polixena (\$24), hija de Príamo: los troyanos citan a Aquiles haciéndole creer que va a casarse con ella, y Paris lo mata (p. 427); sobre Tetis (§ 25), p. 41; sobre Áyax (§ 29), pp. 428-430.

5 Ambas debidas a V. Cristóbal: «Mitología clásica en la literatura española: consideraciones generales y bibliografía», Cuadernos de Filología Clásica. Estudios Latinos, 18 (2000), pp. 29-76, y «Pervivencia de autores latinos en la literatura española: una aproximación bibliográfica», Tempus, 26 (2000), pp. 5-76.

6 M. de Cervantes, El ingenioso hidalgo don Quijote de la Mancha, ed. L. A. Murillo, Madrid, Castalia, 1982², II, pp. 155-156; E. Orozco, Cervantes y la novela del Barroco (del «Quijote» de 1605 al «Persiles»), ed. J. Lara Garrido, Granada, Universidad, 1992, p. 373 (para la génesis andaluza del Quijote, pp. 113-128 y 328-362).

7 G. Garrote Bernal, «Intertextualidad poética y funciones de la poesía en el Quijote», Dicenda, 14 (1996), pp. 113-127 (reeditado en G. Garrote Bernal, Por amor a la palabra. Estudios sobre el español literario, Málaga, Universidad, 2008, pp. 69-87).

8 J. Lara Garrido, «Sonetos epicédicos en homenaje del "divino" Herrera, o el rastro tenue de una fama póstuma», Revista de Estudios Antequeranos, 5 (1999), pp. 35-36 y n. 25; J. Roses, «Agustín de Tejada Páez y la poesía heroica (con algunas notas sobre el magisterio de Herrera)», Revista de Estudios Antequeranos, 5 (1999), p. 69. Cfr. infra, § 46.

9 S. B. Vranich, ed., Obra completa de Don Juan de Arguijo (1567-1622), Valencia, Albatros Hispanófila, 1985, p. 114, que además no suma bien los trabajos de Hércules mencionados por Arguijo; A. Carreira, «Poesía de circunstancias: epitafios a la duquesa de Lerma (1603)», en G. Cabello Porras y J. Campos Daroca (eds.), Poéticas de la metamorfosis. Tradición clásica, Siglo de Oro y modernidad, Málaga-Almería, Universidades, 2002, p. 323. 
y a la complicación y la maestría formales de Arguijo $(\S 6)^{10}$ y Tejada $(\S 28)^{11}$. Para las parejas de poeta y comentarista $(\S 1)$ me sirvo de un artículo mío ${ }^{12}$; y para el concepto de humanismo contrarreformista (§§ 1, 5 y 9), de otro de Valderrama Andrade ${ }^{13}$.

40. Sobre la disposición de las Flores de poetas ilustres $(\S 2)^{14}$, añádase a lo ya dicho ${ }^{15}$ que "una diversidad de lectores hallaría cumplidas sus expectativas" en la "complejidad de significaciones" con que "la figura de Espinosa como ordenador" configura su colectánea, mediante "la introducción paulatina de un lenguaje mucho más cultista" y enlazando los textos con "un sintagma retomado" o "una imagen contigua", disposición que construye "el sentido ideológico final de la antología", según "un entramado intelectual, ajeno a la lógica de la razón"16. Este último enunciado, único poco afortunado de la brillante exposición de Molina Huete, muestra hasta qué punto las presentaciones ahistóricas sobre el manierismo se hallan acríticamente incorporadas a nuestro acervo. Al criterio geográfico de Espinosa apuntó Díez Fernández para fundamentar la selección de tres antequeranas, autoras de dos poemas religiosos y cinco laicos, lo que rompe, "azarosa o conscientemente”, la asociación áurea entre literatura religiosa y femenina ${ }^{17}$.

10 Vranich, ed. cit., pp. 168 y 181; V. Cristóbal, «Virgilio en los sonetos de Juan de Arguijo», Cuadernos de Filología Clásica. Estudios Latinos, 4 (1993), p. 266.

11 Roses, «Agustín de Tejada...», pp. 77 y 86 (para su x-membración, pp. 74, 83 y 86; para su selección léxica de objetos bélicos, p. 84); J. Lara Garrido, «Silva antequerana (II). (Notas de asedio a la poesía antequerano-granadina del Siglo de Oro)», Revista de Estudios Antequeranos, 3 (1995), p. 143.

12 G. Garrote Bernal, «Ensayo de memoria herrerianista hacia la poesía sevillana del siglo XVII», en Congreso Internacional Andalucía Barroca, III. Literatura, Música y Fiesta. Actas, Bilbao, Junta de Andalucía, 2009, p. 119.

13 C. Valderrama Andrade, «Jiménez de Quesada y el humanismo contrarreformista», Thesaurus, 20 (1965), pp. 213-240.

14 B. Molina Huete, «Las Flores de poetas ilustres de Pedro Espinosa en sus ediciones del siglo XIX. Cosas de "marquetería literaria"», Canente, 1 (2001), pp. 115-116.

15 G. Garrote Bernal, «Barahona de Soto en las Flores de poetas ilustres de Espinosa», en J. Lara Garrido (ed.), De saber poético y verso peregrino. La invención manierista en Luis Barahona de Soto, Málaga, Universidad, 2002, pp. 47-68; B. Molina Huete, La trama del ramillete. Construcción y sentido de las «Flores de poetas ilustres» de Pedro Espinosa, Barcelona, Fundación José Manuel Lara, 2003.

16 B. Molina Huete, «Manierismo y antología. Las Flores de poetas ilustres de España ordenadas por Pedro Espinosa (1605)», en Poéticas de la metamorfosis..., pp. 95-116. Los siete primeros poemas de la antología (§ 2), en P. Espinosa, Flores de poetas ilustres, ed. B. Molina Huete, Sevilla, Fundación José Manuel Lara, 2005, pp. 29-41.

17 J. I. Díez Fernández, «Tres mujeres en las Flores de poetas ilustres (1605)», en P. Pérez y E. Postigo, (eds.), Autoras y protagonistas, Madrid, Instituto Universitario de Estudios de la Mujer-UAM, 2000, pp. 83-95. 
41. En los poemas de los tres autores careados (§3), mantengo las numeraciones de las ediciones que empleo: ed. Garrote-Cristóbal para los nueve sonetos de Arguijo (I, XXIII, XXIV, XXVII, XXXV, XXXIX, XLV, LII y LXVI) ${ }^{18}$; ed. Morata para los diez de Martín de la Plaza (LIII, LVI-LX, LXII, LXV, LXVII y LXVIII) ${ }^{19}$. En cuanto a los cinco de Tejada (\$ 24) $)^{20}$, figuran en Variedad de sonetos, núms. 106-108 21 y Poética silva, núm. 2722; Lara Garrido publicó el que rotulo T $1980^{23}$. A veces semimodernizo los textos e introduzco ciertos cambios de puntuación en algunos sonetos de Tejada y De la Plaza. En T 108 (§ 27), corrijo el v. 11, donde creo que el verbo (han) debe ir en plural.

42. En el $\S 3$ menciono la canción atribuida a Arguijo por Calderón, y la edición y estudio de «A las once mil vírgenes», de Martín de la Plaza ${ }^{24}$; también, los recuentos de las presencias de Arguijo, Tejada y De la Plaza en la Poética silva (h. 1602), las Flores de 1605 (Espinosa) y 1611 (Calderón), y Cancionero antequerano, I o Variedad de sonetos $(1627)^{25}$, colectáneas que silenciaron a Herrera ${ }^{26}$. Estas cuatro colecciones brindan

18 J. de Arguijo, Poesía, ed. G. Garrote Bernal y V. Cristóbal, Madrid, Fundación José Manuel Lara, 2004, pp. 5, 41, 43, 47, 61, 68, 79, 90 y 170. Esta edición y su estudio han resultado sumamente calcados en J. de Arguijo, Poesía completa, ed. O. Miró Martí, Madrid, Cátedra, 2009 (cfr. G. Garrote Bernal, «Una edición contrahecha de Arguijo (I)», AnMal Electrónica, 28 [2010], pp. 197-223 [http:/ / www.anmal.uma. es/numero28/Edicion_Miro.pdf]).

19 L. Martín de la Plaza, Poesías completas, ed. J. M. Morata Pérez, Málaga, Diputación, 1995, pp. 120, $125-129,131,134$ y 136-137.

20 B. Molina Huete, «Agustín de Tejada y las Flores de poetas ilustres de Pedro Espinosa», Analecta Malacitana, 24 (2001), pp. 362-365.

21 J. Lara Garrido, ed., [Cancionero Antequerano] I. Variedad de sonetos, Málaga, Diputación, 1988, pp. 9192. Esta antología inserta también A 23, A 24 y los diez sonetos de Martín de la Plaza que estudio.

22 I. Osuna, ed., Poética silva. Un manuscrito granadino del Siglo de Oro, Córdoba-Sevilla, Universidades, 2000, I, pp. 57-59 y 199. Tejada no sólo es el único representante antequerano en esta colección (I, p. 22, n. 39), sino el poeta de los diecisiete ahí presentes del que se acoge un mayor número de textos, hasta doce (II, pp. 277-278), a los que pudieran sumarse otros ocho sonetos, según Michäelis, y un romance, al decir de Orozco: cfr. J. Lara Garrido, Del Siglo de Oro (métodos y relecciones), Madrid, Universidad Europea, 1997, p. 235, nn. 11-12.

23 J. Lara Garrido, «Notas sobre la poética de las ruinas en el Barroco», Analecta Malacitana, 3 (1980), p. 397.

24 Para el primer poema, que no forma parte del canon de Arguijo, cfr. ed. Vranich, pp. 46-47, y ed. Garrote-Cristóbal, pp. cxxix-cxxx; para el segundo, Lara Garrido, «Silva antequerana (II)...», pp. 129-138.

25 Vranich, ed. cit., p. 52, cuenta cinco (y no seis) sonetos arguijianos en las Flores de Espinosa, dato corregido por Molina Huete, La trama del ramillete..., p. 181, n. 155; para los 23 (y no 24) sonetos de Arguijo en las Flores de Calderón, ed. Garrote-Cristóbal, p. cxxix, n. 266. Roses, art. cit., pp. 64-65, recuerda la presencia de Tejada en las antologías mencionadas, y Morata, ed. cit., pp. 49-50, la de Martín de la Plaza, el autor más antologado en la de Calderón (Molina Huete, «Manierismo y antología...», p. 103).

26 J. Morata Pérez, «Ecos de Fernando de Herrera en Luis Martín de la Plaza: asimilación y lejanía», 
fechas - meramente orientativas - que apoyaran la comparación de los sonetos que he comentado ${ }^{27}$ : T 27, antes de 1602; MP 68, antes de 1605; T 106-T 108 y MP 53, 5660, 65 y 67, antes de 1611; MP 62, antes de 1627. Cuando cerró su primera redacción, Arguijo envió sus sonetos a Medina entre 1599 y 1605 (A 66 seguramente es posterior a esta última fecha $)^{28}$.

43. Apliqué el concepto de ironía de situación (§ 4) en un trabajo aún inédito; para los lexemas de referencia mítica encubierta y automatizada (\$ 11), me valgo de un artículo mío ${ }^{29}$. Sobre Hércules (§ 5), Morata recuerda el soneto de Lupercio L. de Argensola, "Al hijo fuerte del mayor Planeta...", publicado en las Flores de 1605 y cuyo inicio es semejante al de MP $67^{30}$. Argensola, que como De la Plaza se fija en la madrastra (v. 6) de Hércules, emplea esta historia mítica para consolar, en el último terceto, «A un gran señor a quien resultaron disgustos de haber su padre contraído segundo matrimonio», según reza el epígrafe ${ }^{31}$. Para el mito de Apolo y Dafne, recurro a los artículos de Castro Jiménez y de Marasso (§ 8), a la comparación con Quevedo (§ 9) y a la traducción ovidiana de Sánchez de Viana (\$§ 9-11) ${ }^{32}$. Sobre Ariadna y Teseo menciono el trabajo catuliano de Arcaz Pozo $(\S 13)^{33}$. Lida de Malkiel precisó que Elisa y Dido "parecen antiguos vocablos fenicios" que ya se encuentran en la Eneida, y dijo respecto a Fenisa, "gentilicio de Dido" y "nombre que hizo bastante fortuna en el Siglo

Revista de Estudios Antequeranos, 5 (1999), p. 146, y Garrote Bernal, «Ensayo de memoria herrerianista...», pp. 124-126.

27 La datación h. 1602 de la Poética silva, en Osuna, ed. cit., I, p. 20.

28 Garrote-Cristóbal, ed. cit., pp. cxxiii-cxxiv.

29 G. Garrote Bernal, «El Acteón y Diana de Antonio Mira de Amescua», en La mitología en el Siglo de Oro (Facultad de Filología de la Universidad Complutense, Madrid, 11-XII-2000), donde indiqué: “La ironía de situación hace que todos (el poeta que narra y se inmiscuye en los hechos, y los lectores, cuya memoria ovidiana anticipa el desenlace) conozcamos lo que espera al desprevenido Acteón". Para el segundo asunto, G. Garrote Bernal, «Tradición mitológica y contextualización literaria: Prometeo en la lírica española del Siglo de Oro», Cuadernos de Filología Clásica. Estudios Latinos, 4 (1993), p. 255 (reeditado en Garrote Bernal, Por amor a la palabra, pp. 39-68).

30 L. Martín de la Plaza, Poesías completas, p. 136, n. 22.

31 L. L. de Argensola, Rimas, ed. J. M. Blecua, Madrid, Espasa-Calpe, 1972, p. 172.

32 M. D. Castro Jiménez, «Presencia de un mito ovidiano: Apolo y Dafne en la literatura española de la Edad Media y el Renacimiento», Cuadernos de Filología Clásica, 24 (1990), p. 213; A. Marasso Roca, «Luis Martín de la Plaza (apuntes para un estudio)», Humanidades [Universidad Nacional de la Plata], 1 (1921), p. 261; F. de Quevedo, Poesía original completa, ed. J. M. Blecua, Barcelona, Planeta, 1981, pp. 562-563; Ovidio, Las metamorfosis, ed. J. F. Alcina, Barcelona, Planeta, 1990, pp. 24-28.

33 J. L. Arcaz Pozo, «Catulo en la literatura española», Cuadernos de Filología Clásica, 22 (1989), pp. 261263. 
de Oro", que también figura en Virgilio $(\S 15)^{34}$. Para la vertiente seria del relato sobre Dido y Eneas - tan opuesta a su parodia $(\S 16)^{35}-$, considérese que Ruiz de Elvira, para quien las razones aducidas por el héroe para abandonar a la reina son "puros pretextos", añadió a las acusaciones contra la falsedad de Eneas el testimonio de san Agustín, Confesiones, I, 13, “casi con seguridad" referido a la Eneida ${ }^{36}$; sin embargo, la actitud de Dido representaba "lo antirromano": enamorándose del héroe, "se opone al fatum, falta a su pietas hacia Siqueo y descuida su ciudad", por lo que "la condena" es consecuencia lógica ${ }^{37}$.

44. De Arguijo explayo los sonetos A 52 (§ 6) ${ }^{38}$; A 24 (§ 10) $)^{39}$; A 23 (§§ 11-12) A 39 (§ 13) $)^{41}$; A 35 (§ 30) ${ }^{42}$; A $66\left(\S \S 34^{43}\right.$ y $\left.35^{44}\right)$; para A $27(\S 26)^{45}$ prescindo del largo análisis estilístico-acentual en que Vranich subraya el "bello juego de palabras" del último terceto, que "resume el núcleo del tema", y en que sostiene inexplicablemente que "hay una rica modulación andaluza sobre todo en el breve discurso que pronuncia

${ }_{34}$ M. R. Lida de Malkiel, Dido en la literatura española. Su retrato y defensa [1942], Londres, Tamesis, 1974, pp. 16-17 y 97 (y sobre la onomástica mencionada, pp. 4 y 30).

35 Tengo en cuenta sobre estas burlas a Quevedo, Poesía original completa, p. 578, y a Lida de Malkiel, op. cit., pp. 51, 143 y 30 .

36 A. Ruiz de Elvira, «Dido y Eneas», Cuadernos de Filología Clásica, 24 (1990), pp. 87 y 84.

37 M. F. Campelo Issaly y J. Cardigni Morales, «Muerte fundadora: la Eneida de Virgilio», Cuadernos de Filología Clásica. Estudios Latinos, 20 (2001), p. 60.

38 Menciono, como en las notas siguientes, los comentarios que cito: ed. Vranich, pp. 113-114 y 116, y ed. Garrote-Cristóbal, pp. 90-91.

39 Vranich, ed. cit., p. 164.

40 Vranich, ed. cit., pp. 167-169.

${ }^{41}$ Prieto, op. cit., II, p. 544; ed. Vranich, pp. 181-183.

42 Vranich, ed. cit., p. 190, acopia las fuentes clásicas sobre el asunto. Como término de comparación, Quevedo, Poesía original..., pp. 511-512.

43 G. Cabello Porras, «Del paradigma clásico a una apertura significacional en el motivo de las ruinas a través de la poesía de Herrera», Analecta Malacitana, 4 (1981), pp. 313-314, menciona los otros tres poemas de Arguijo sobre el asunto, sobre los que trataron asimismo Lara Garrido, «Notas sobre la poética de las ruinas...», pp. 230-231, y E. Orozco, quien de A 3, vv. 12-14, indicó que "la misma ruina supondrá el acrecentamiento de este valor" moral o espiritual de la antigua civilización; y de A 2, vv. 12-14, que la "idea de remedio" "la encontramos repetida en Arguijo, pero filtrándose ya la nota escéptica" («Ruinas y jardines. Su significación y valor en la temática del Barroco» [1943], Temas del Barroco. De poesía y pintura, Granada, Universidad, 1947, p. 132).

44 Lara Garrido, «Notas...», p. 391; Vranich, ed. cit., p. 276.

45 La «Canción a san Acacio», que menciono a propósito de este soneto, fue editada por Lara Garrido, «Silva antequerana (II)...», pp. 130 y 135. 
Alejandro"46; A 1 (§§ 15 y 18) y A 45 (§§ 15-18) ${ }^{47}$; sobre Infelix Dido... y sus derivaciones (§17), atiendo a Alatorre ${ }^{48}$, quien, partiendo de Lida de Malkiel ${ }^{49}$, estudia descendientes del famoso dístico, como el de Bartolomé de Argensola, “Dido infeliz...", publica una imitación de A 45, el soneto anónimo "Muere Siqueo; Elisa desdichada...", y sugiere que el motivo de Infelix Dido sería asunto tratado en la academia portuguesa de los Generosos (pp. 312 y 315).

45. De Martín de la Plaza comento MP 68 (§§ 8 y 12) $)^{50}$; MP 65 (§§ 13-14) MP 57 (§§ 17 y 20) ${ }^{52}$; MP 56 (§ 19) ${ }^{53}$, con dos observaciones generales que proceden respectivamente de Alatorre y Carreira ${ }^{54}$; MP 58-60 (§§ 21-26 $6^{55}$ ); en el $\S 23$ refuto la interpretación de Carreira sobre MP 5856, basándome en Quevedo y García de la Fuente $^{57}$, y atiendo al gongorismo de Martín de la Plaza advertido por Marasso y

46 Vranich, ed. cit., pp. 246-248.

47 Cristóbal, «Virgilio», pp. 258-259 y 265; ed. Vranich, pp. 256 y 251-252; Prieto, op. cit., II, p. 538.

48 A. Alatorre, «Dido y su defensa (traductores españoles y portugueses de dos epigramas atribuidos a Ausonio)», Filología, 8 (1962), pp. 308 y 311.

49 Lida de Malkiel, op. cit., pp. 4, 17 y 62-66.

50 Lara Garrido, ed. cit., p. 273. En el § 8 añado una observación general de A. Carreira, «Luis Martín de la Plaza, o el manierismo en Antequera», Analecta Malacitana, 20 (1997), p. 303.

51 Vranich, ed. cit., pp. 183-184; Lara Garrido, ed. cit., pp. 286-287, quien también apunta la dependencia de MP 63 respecto de A 11, dos sonetos sobre Pompeyo. Puntúo MP 65, v. 13 (§ 13) con las dos comas que pide Carreira, "para conectar dan con su complemento directo" («Luis Martín de la Plaza...», p. 300), y lo mismo hago en el v. 9, tras Vuelve y dice.

52 Lara Garrido, ed. cit., p. 279; B. Gracián, Agudeza y arte de ingenio, ed. E. Correa Calderón, Madrid, Castalia, 1969, II, p. 158. Michaëlis adjudicó a Tejada "Dulces recuerdos de pasada gloria...", soneto de la Poética silva que Carreira coteja con MP 57 («Luis Martín de la Plaza...», pp. 299-300).

53 Lara Garrido, ed. cit., p. 271.

54 A. Alatorre, «Notas filológicas en torno a las poesías de Luis Martín de la Plaza», Nueva Revista de Filología Hispánica, 45 (1997), p. 440; Carreira, «Luis Martín de la Plaza...», p. 306.

55 Marasso Roca, art. cit., p. 258, indicó que Met., XII y XIII son las fuentes respectivas de MP 58 y MP 59, información que completa Lara Garrido, ed. cit., pp. 271, 314 y 316: Met., XII, 615-617 (MP 58), Antología griega y Met., XIII, 499-500 (MP 59) y Antología griega y Odisea, XXIV, 40-84 (MP 60).

56 Carreira, «Luis Martín de la Plaza...», p. 300.

57 Quevedo, Poesía original..., p. 37; O. García de la Fuente, «El latín bíblico y el latín cristiano en el marco del latín tardío», Analecta Malacitana, 10 (1987), p. 58, y Latín bíblico y latín cristiano, Madrid, CEES, 1994, pp. 62-63. 
reiterado por Alatorre ${ }^{58}$; MP 59 (§ 24) ${ }^{59}$; MP 60 (§ 25) ${ }^{60}$; MP 62 (§ 29) $)^{61}$, y MP 53 (§§ $33^{62}$, $34^{63}$ y 35). Para los cabellos en T 106 y MP 59 (§ 24$)^{64}$, tengo en cuenta lo indicado por Colón, con amplia documentación de contraste sobre el éxito del tema de Polixena en la poesía del XVI ${ }^{65}$.

46. A propósito de T $106(\S 24)^{66}$, Lara Garrido trae la cita pertinente de la versión que ofrece Barahona de "el sacrificio y la queja" de Polixena ${ }^{67}$. A Barahona ofrendó Tejada el soneto funeral T $112^{68}$, tratado, junto con el dedicado a Herrera (T 111) y con los dos de Cristóbal de Mesa sobre los mismos asuntos, por el citado estudioso ${ }^{69}$. T 111 interesa también por la relación existente entre la teoría y la práctica poética herrerianas, que asume Tejada quizá con mayor coherencia que el propio sevillano ${ }^{70}$. Por lo demás, Arguijo, Tejada y Martín de la Plaza coincidieron en alabar con sonetos a Lope de Vega (§ 25), aunque el tercero terminó enfadándose con él ${ }^{71}$.

58 Marasso Roca, art. cit., p. 254; Alatorre, «Notas...», pp. 441-443.

59 Morata Pérez, ed. cit., p. 128, n. 7. Pirro también asesinó a Príamo, padre de Héctor y Polixena, y marido de Hécuba (sobre el fallecido rey de Troya, cfr. A 59 [Arguijo, Poesía, ed. Garrote-Cristóbal, pp. 100-101]).

60 El erróneo dictamen de Carreira que menciono, en «Luis Martín...», p. 300. Para el soneto de Martín de la Plaza a Lope, cfr. Lara Garrido, ed. cit., pp. 81 y 143.

61 Lara Garrido, ed. cit., pp. 316-317, que apunta a Met., XIII, 384-390 como “el arranque y el concepto explanado en los tercetos" de MP 62. Para Carreira, «Luis Martín...», p. 300, este soneto "tiene deturpados los vv. 3-4. El segundo terceto deriva de los epigramas VII 147-149 (este en especial) de la Antología Palatina"; para el sustantivo sin actualizador, R. Lapesa, Estudios de morfosintaxis histórica del español, ed. R. Cano y M. T. Echenique, Madrid, Gredos, 2000, I, pp. 455, 461, 463 y 468.

62 Lara Garrido, ed. cit., p. 278.

63 Aprovecho indicaciones de Lara Garrido, «Notas...», pp. 388-391, y ed. cit., p. 278.

64 Morata Pérez, ed. cit., p. 128, n. 8; Marasso Roca, art. cit., p. 258. A propósito de los certámenes poéticos, A. Egido, Fronteras de la poesía en el Barroco, Barcelona, Crítica, 1990, pp. 115-163.

65 I. Colón, «Elegías funerales en la poesía de Barahona de Soto», en De saber poético..., pp. 270-277.

66 D. Cotta Lobato, «La qualitas sonorum como recurso expresivo en la poesía de Agustín de Tejada», Canente, 1 (2001), p. 214; Lara Garrido, ed. cit., p. 290, lugar donde apunta asimismo al anónimo soneto 371 del Antequerano, I (p. 205) como imitador de T 106, si no es "una segunda versión del mismo" (pp. 341-342).

67 Lara Garrido, ed. cit., p. 290.

68 Lara Garrido, ed. cit., p. 94.

69 Lara Garrido, «Sonetos epicédicos...», pp. 47-57.

70 Cotta Lobato, art. cit., pp. 189-190, 201-202 y 216-217.

71 Arguijo, Poesía, ed. Garrote-Cristóbal, pp. xxxi, li y 169; D. Alonso, «Lope en Antequera» [1935], Obras completas, III, Madrid, Gredos, 1974, pp. 929-936, para quien el “excelente poeta” Martín de la Plaza es 
47. De Tejada explayo otros cuatro sonetos: T $107(\S 31)^{72} ; \mathrm{T} 27(\S 32)^{73} ; \mathrm{T} 1980$ (§ $36)^{74}$, y T $108(\S \S 27-28)$.

48. En cuanto a la poesía funeral $(\S 27)^{75}$, he atendido a la nacionalización del epitafio de raíz clásica $(\$ 31)^{76}$. El soneto epitafio (\$ 30$)^{77}$ presenta una "retórica elevada" y "fórmula ecfrástica y alocutiva de la inscripción sepulcral", frente al soneto epicédico u "homenaje a lo más excelente del sujeto desaparecido", realizado mediante la "ficción de recitado delante del monumento funerario"78. Carreira recuerda epitafios para personajes ficticios (entre ellos, los de Quevedo a Aquiles y a Mucio Escévola), y atiende a la moda que, con el antecedente del libro VII de la Antología palatina, formó en el siglo XVII colecciones de "epitafios y similares"79. De los sonetos epitafio de Tejada dedicados a personajes reales españoles (la duquesa de Lerma [T 118], Narváez [T 145] y el Gran Capitán [T 198]), Carreira compara T 118 con poemas sobre el mismo asunto de Quevedo, el conde de Salinas y Góngora. T 118 llama al mausoleo funeral Atlante (v. 4; cfr. MP 67, v. 14, segundo Atlante), mediante un mecanismo semejante al de Quevedo, "Aqueste es el poniente y el nublado / donde el tiempo Nerón tiene escondido..."; al puntuar Nerón entre comas, Carreira lo interpreta como vocativo, y en consecuencia afirma que es "lo único que sobra", "por introducir una isotopía de distinto orden"80; pero no se da cuenta este crítico de que Nerón, asociado por Quevedo al fuego, es aquí aposición que añade a tiempo el significado de 'que todo lo quema o destruye'.

"un sonetista que sabía su oficio"; Roses, «Agustín de Tejada...», pp. 67-69; Molina Huete, «Agustín de Tejada...», pp. 358-359.

72 Lara Garrido, ed. cit., p. 290, que ofrece también las dos variantes que he comentado; Cotta Lobato, art. cit., pp. 196, 207 y 190.

73 Osuna, ed. cit., II, pp. 57 y 182-183; para el correlato con Quevedo, Poesía original..., p. 599.

74 Cotta Lobato, art. cit., p. 192; Lara Garrido, «Notas...», p. 399. Para los vínculos de T 1980, cito respectivamente a S. B. Vranich, Ensayos sevillanos del Siglo de Oro, Valencia, Albatros Hispanófila, 1981, p. 68, n. 21 (con Mesa), el texto del Antequerano, ed. Lara Garrido, p. 89 (con T 101) y ed. Vranich, p. 277 (con A 66).

75 Carreira, «Poesía de circunstancias...», pp. 325 y 340; Lara Garrido, «Sonetos epicédicos...», p. 32; J. Morata Pérez, «En torno al granadino Andrés del Pozo y algunos textos inéditos de la Poética silva», Canente, 1 (2001), pp. 23, 26 (n. 38) y 45-62 (cuidada edición y anotación de la «Oda al Tiempo», en espinelas).

${ }^{76}$ Carreira, «Poesía de circunstancias...», p. 325, que menciono a propósito de Quevedo.

77 Marasso Roca, art. cit., pp. 271 y 272, n. 1.

${ }^{78}$ La distinción es de Lara Garrido, «Sonetos epicédicos...», p. 32.

79 Carreira, «Poesía de circunstancias...», pp. 323 y 325.

80 Carreira, «Poesía de circunstancias...», pp. 331-332. El texto de Quevedo, en Poesía original..., pp. 593 y 877. 
49. En uno de los estudios que cito respecto a las ruinas $(\S 33)^{81}$, Orozco indica que el discurrir del Barroco aumenta la frecuencia de este asunto, orientado hacia "la agudización del sentido de lo temporal y la visión pictórico-pintoresca", en lo que "el arqueólogo no se deja ocultar por el poeta". Entonces se abandona la "clásica admiración a las ruinas de Roma", sustituidas sobre todo por "las de Itálica y las de Sagunto", lo que conlleva nuevos significados: el "amor patrio" y "la decadencia política". Además, he tenido en cuenta lo dicho sobre De Roma, de Vitalis $(\S 34)^{82}$. Esta fuente común de Quevedo y Martín de la Plaza, no conocida por Marasso, hizo entender a éste que MP 53 "no ha imitado a Quevedo sino traducido con algún acierto a Du Bellay"83. Pariente de la moralización cristiana del tema de las ruinas $(\S 35)^{84}$ es el característico arqueologismo contrarreformista $(\S 36)^{85}$ : comulgan ambos en la recuperación de un pasado que se sabe - o al menos se quiere - ideológicamente operativo, como evidencian el Arco de los Gigantes (§§ 36-37) y sus poemas e inscripciones neolatinos, que Tejada acogió en los Discursos históricos de Antequera, II, III ${ }^{86}$.

81 Lara Garrido, «Notas sobre la poética de las ruinas...», pp. 385-387 y 393-394; Orozco, «Ruinas y jardines...» pp. 128-131 y 122-137; Vranich, Ensayos sevillanos..., pp. 64-72; Prieto, op. cit., II, p. 411; J. Lara Garrido, «El motivo de las ruinas en la poesía española de los siglos XVI y XVII. (Funciones de un paradigma nacional: Sagunto)», Analecta Malacitana, 6 (1983), pp. 223-277; J. Siles, «Prólogo. De la emoción lírica de un algo a la reconstrucción histórica de un todo», en F. J. Pérez i Durà y J. M. Estellés i González, Sagunt. Antigüedades e ilustración, Valencia, Alfons el Magnànim, 1991, pp. 7-17.

82 Siles, «Prólogo», pp. 8-9; Lara Garrido, «Notas sobre la poética de las ruinas...», pp. 388-391, y ed. cit., p. 278. El texto de Quevedo aludido, en Poesía original..., pp. 260-261.

83 Marasso, art. cit., pp. 268-270.

${ }^{84}$ Lara Garrido, «El motivo de las ruinas...», p. 250.

85 Lara Garrido, «Notas sobre la poética de las ruinas...», p. 398.

86 A. de Tejada Páez, Discursos históricos de Antequera, ed. A. Rallo Gruss, Málaga, Diputación, 2004, II, pp. 66-70. 